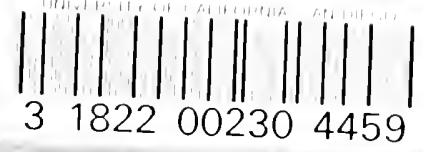

\title{
JOHN COAKLEY LETTSOM
}

AND THE FOUNDATION OF

\section{THE MEDICAL SOCIETY.}

\author{
BEING THE \\ PRESIDENTIAL ADDRESS \\ DELIVERED BEFORE \\ THE MEDICAL SOCIETY OF LONDON \\ ON
}

October 8th, 1917,

BY

SIR STCLAIR THOMSON,

M.D., F.R.C.P. LOND., F.R.c.S. ENG.

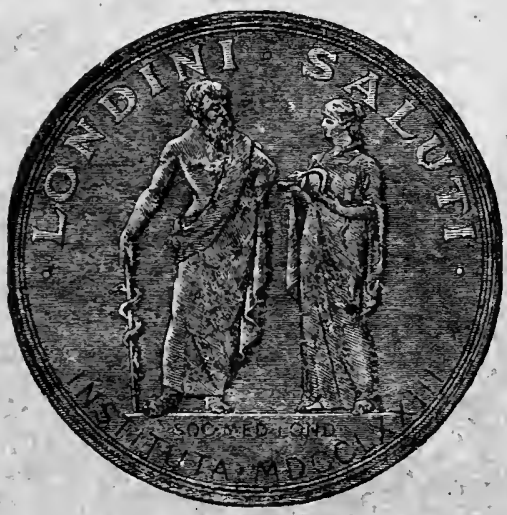

LONDON :

HARRISON AND SONS, ST. MARTIN'S LANE, W.C.

PRINTERS IN ORDINARY TO HIS MAJESTY.

\section{8 .}

Price Two Shillings and Sixpence. 



\section{Digitized by the Internet Archive in 2008 with funding from Microsoft Corporation}




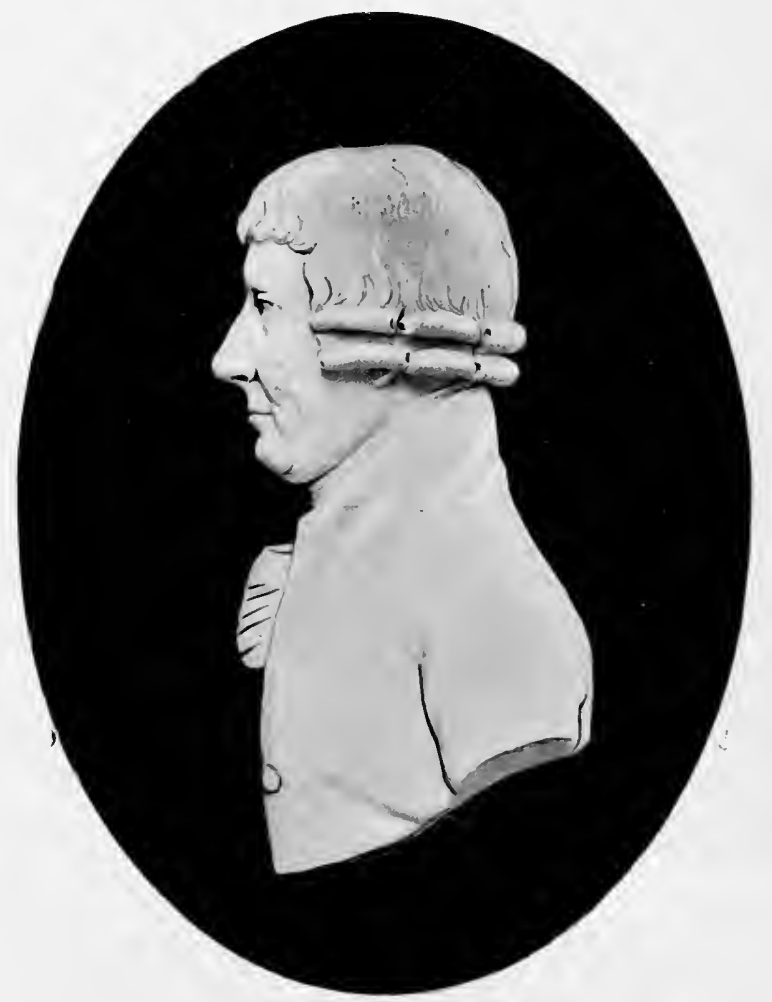

FIfi. 1.-John Coakley Lettsom, M.1), F.R.S.

(From a wax medallion in the gossession of $\mathbf{M r}$. John II. A. Jlliot, great-great-gramilson of Dr. Lettsomil.) 


\section{JOHN COAKLET LETTSOM}

ANI) THE MOENATION OH

\section{THE MEDOCAL SOCHETY.}

HEINI: IIII:

\section{PRESIDENTIAL ADDRESS}

DELIVEREJ) DEF(HIE:

- the medical societte of lovion

ON

Oetolier sthe 1!17,

i:

SIK STCLAIR THOMSON,

M.D, F.R.C.P. I.OND., F.R.t.s. F.NG.

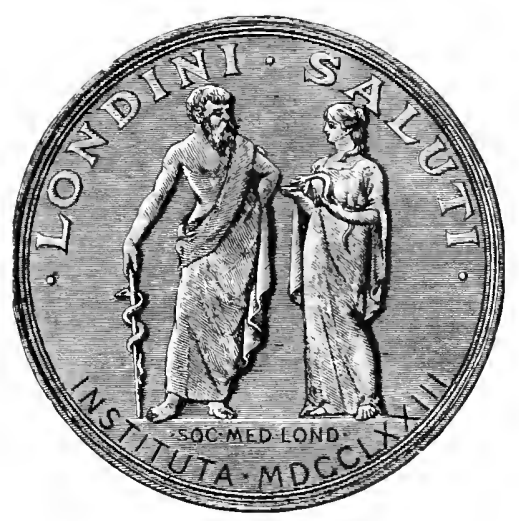

\section{LONDON :}

HARRISON ANU SONS, ST. MARTIN'S LANE, W.

PRINTERS IN ORDINARY TO HIS MAJESTY.

$\overrightarrow{1918}$.

Irice T'uo Shillings: and sirpenee. 

Witule, sth, 1917.

\title{
.JOHN COAKLEY LETTSON
}

ASI THE FOUNHATIOS IF

THE MEDHC SOCHETS

\author{
Prestidental AdDrens. \\ By sir sted.ant THomson, M.I., F.R.C.P. Lomul., \\ E.R.C.S. Eng. \\ INTRODUCTION.
}

Fellows of the Medcal. Sochety and Visitulis, - Some one has said that there are two happy periods in the life of a President; the first being when he assumes the dignity of the Chair, and the second when he resigns the cares of office. Personally, I feel that fate will cheat me of both these moments, for I am sure that with the kind and efficient help of the Seeretaries and Registrar, and the wise and loyal guidance of the Couneil, we will have sueh a successful session that I will part with the Presideney with regret. As to the promised happy moment of this evening, I view it with dismay. Many distinguished Presidents have oecupied this office since the foundation of the Society in 1773 . In addition to the well-knowin names of physicians, surgeons, and gynæcologists inseribed on our walls, I notice those of colleagnes who have devoted themselves to nerrous and mental diseases, while in Erasmus Wilson in 187R, Brudenell Carter in 1886, and William Dally in 1894, the specialities of dermatology, ophthalmology and otology have been recognised. I feel that the honour of being electerl to this honourable and responsible office has fallen to my lot as a repre- 
sentative of laryngology, a comparatively young speciality and for a long time the Cinderella of the sisterhood. On hehalf of $m y$ co-workers in this department of practice I heartily thank the Society for this first recognition, and I deeply appreciate my good fortune in reeeiving the highest honour whieh ean be bestowed by one's Fellows in this, the oldest of the Medical Societies of London.

I naturally turned to our Rules, the history of our Foundation, and the life of our Founder to guide me in the act of presiding. The outstanding personality of the Medical Society is, and always must be, John Coakley Lettsom. I have found the records of his life so interesting that I trust I may be forgiven if I occupy part of this evening in trying to convey the impression I obtained of him during my researches into the duties of the office of President.

\section{LetTson's Early Life.}

John Coakley Lettsom was born in 1744 and died in 1815 . He was one of the seven twins of his parents, and he and his brotherthe seventh pair-alone survived infancy. The following sketeh of his eareer may be more interesting if we recollect that he had no great social or family influence, that he never attended any noted school or had a regular university eourse, that he was not a Fellow of the College of Physicians, that he never held any Court appointment and was not on the staff of any well-known London Hospital. He may have had his good turns of fortune, but he had few advantages in his birth, education and up-bringing, and the suceess of his evidently healthful, happy, vigorous and useful eareer was due almost entirely to his own applieation, his keenness in his profession, his love of humanity, the breadth of his interests, his zest for life, and his happy disposition. He was born in the West Indies and may have had some Freneh blood in his veins, for he refers in a letter to the suggestion, without denying it, that he had the "volatility of the Creole with the plodding incustry of the German." (Fig. 2.) He had no sister and, as he was sent to England at the early age of six, we cannot elaim mueh home influence in forming his character. He never saw his father again. He was sent to a small school of forty or sixty boys at Penketh, in Lancashire, kept by a member of the Society of Friends, for Coakley belonged to a Quaker family and he lies buried in the Friends' Burial Ground, Little Coleman Street (now re-named 


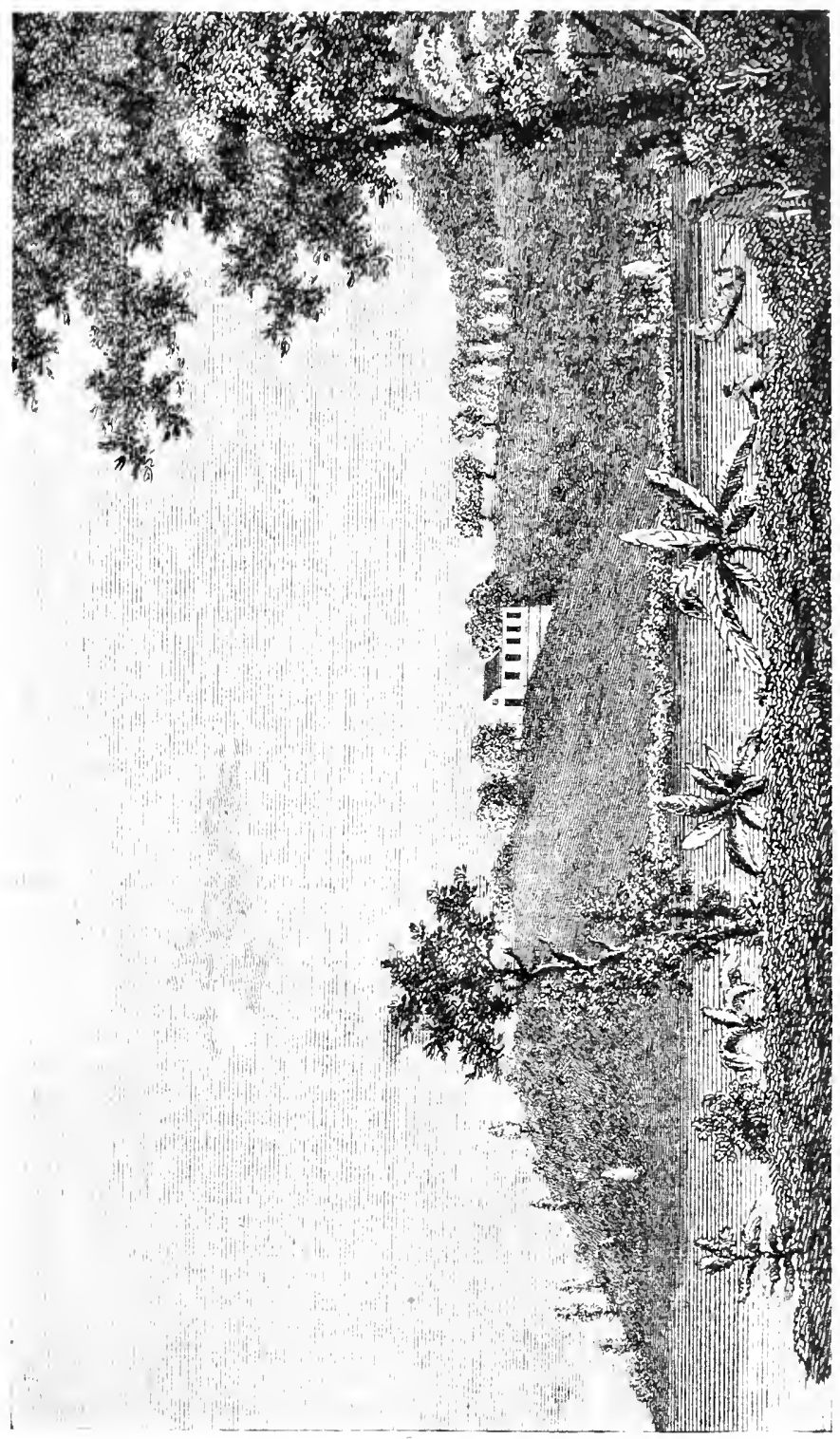


Roscoe Street), Bumbill Row. While at this school, he came under the influence of the well-known Quaker minister, Simnel Futhergill, of Warrington, the rounger brother of the celebrated Dr. John Fothergill, of Lonrlon, and from this more or less aceidental atcquantance, we can trace an influence on the career of Lettsom and the origin of our own Fothergillian Gold Nedal. At this small rlay-school Lettsom only remained until the age of 14 , and during this time, if he learned small Latin and less Greek, he had the much greater advantage of acquiring a knowledge and love of nature by heing allowed and encouraged to join in the usual country sports of school boys of a former generation. Following the hounds on fout, sometimes assisted by pole-jumping; bathing and swimming: the use of bow and arrow ; fishing, sliding, and long days spent in mutting or bird-nesting, not only helped to forin a vigorous and active constitution, hut gave a keemness in observation, a resourcefulness in emergencies, a quickness of eye, and a love of fellowship with nature, which the present generation runs the risk of losing with its exaggeration of formal games confined within monotonons playing grounds. The healthiness of the school is testified to by the fact that during the forty years that this school was nnder the hear-mastership of Lettsom's teacher, only one death occurrerl in the school. American visitors this evening will be interesterl to hear that this was the case of Springett Penn, the son and heir of the Penns of Pennsylvania, and it was said that he was in a consumptive state when he entered the school.

\section{A Medical. Apprentig:}

Lettsom is education finished in his 1 th year. His father was lead, and his mother in the far West Indies had married again. He wis then sent to Liverpool for a business training, but, at the end of a year, circumstances arose which resulted in his being apprenticed as a pupil to Abrabam Sutcliff, a surgeon and apothecary at Settle in Yorkshire. If the school in Lancashire helperl in the promotion of Lettsom's physical vigour and powers of observation, it is to his five years' residence in Yorkshire that we may ascribe the opportumity for the acquisition of a love of learning, much book lore, habits of work, training of memory, and the faculty of managing patients. His master, Sutclift, was in excellent classical scholar, though quite self-taught, 


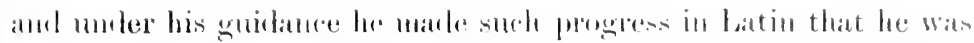
able to sturly in that language the works of linephase. Winslow. and others. We shoulal remember that in the lsth rentmry hation was still a living language, for lettsom, like all phesicians of the time, combl lollow loctures in it at foreign moirersitios, discolss medical matters with colleagues of sarions commtries in latim, and,

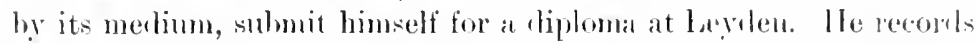
that he "attended the laertures of lunes, Simelair, Phummer, and Rutherforel in that language (i.e. Latin), in which I was protty well qualified to naintain a comrersation or dispmte" (letter lis. Iuly 17th, 1783). With a party of friends he shared the expense of procming a French master from Lomblon, so that he not only (ould rearl the language with ease, but could speak and write it fairly well. He obtained a few Greek hooks, and acquired a little knowledge of that kunguge. This must have been a rastly superion education to the fragmentary knowlerlge of disjointerl grammar of mispronounced Latin, which nowalays takes up so many years of an English hoy's life and results in snch appalling ignorance both of it and of his own tongme.

While at Settle his favourite study was hotany, and thus he laid the foundation for much of his delight in after year's in his weekends at his comutry house at Camberwell. Lettom carly realiserl that he had not a goor memory, and in his lsth year he started the hahit of careful nete-taking and the construction of tahles. "Thus," as his biographer, Pettigrew, records. "with moderate powers of mind, he was able to supply by industry and art what nature had denied him."

$\mathrm{IT}^{\mathrm{e}} \mathrm{e}$ have no record of his purely professional training during these years, from 15 to 20 , when he was apprenticel to a country apothecary and surgeon. But I have myself been articlect as a "nedical pupil" in a provincial town, and am therefore probably amongst the last survivors of a now extinct stage in medical education. Anyhow, it helps me to imagine what many of Lettsom's duties were. Each morning he would have to fill up the stock of mixtures in the surgery, give an eye to the leeches, and inseribe in a large round hand Die Solis, or Die Joris, or the other daily heading in the Day Book. When his master had started in his gig on the morning round, the pupil might have to see and prescribe for a string of chu patients, the inspection of the tongne and the feeling of the pulse lieing the only methods 
of physical examination employerl. Later in the day he might be sent round to visit the chronic cases, change dressings, vaccinate, or even to see how a confinement case was getting on. I attenrled my first midwifery case at the age of 17 , and, while still a medical pupil, I had learned to apply the forceps and perform intra-ıterine version. Much of the afternoon would be occupied in dispensing for the cases his employer had seen during the morning, and no small part of this art would be the neatness and skill with which labels were written out and gummed on, corks were securely inserted, and bottles were wrapped in clean white paper, sealed and addressed. The training this gave in method, order, cleanliness, certainty, and despatch is not to be despised, while the pupil acquired a direct demonstration of the appearance, smell and taste of varions mixtures, the size of pills, and the incompatibility of drugs. Then, pills had to be rolled, and even silvered, powder's had to be pestled, and ointments to be mixed. The cutting and rolling of bandages and the lining of splints would be part of his work. The making of tinctures and infusions, the stirring and dividing of powders, the spreading of blisters, also took up much time in the surgery, and outside of it there would be occasional help at operations, or at setting limbs and reducing dislocations. Amongst the more wearying of his duties would be the daily or weekly "posting up the books," and every quarter or so "the sending out the bills." In Lettsom's days there were no administrations of anesthetics, a duty which devolved chiefly on the apprentice in the days of my pupilage.

Lettsom was apprenticed for five years to a country apothecary; I was a "medical pupil" (which had hecome the designation of the Victorian era) for two years. This stage in medical education is now extinct, and it is not likely that it will ever be revived. Yet it had much to recommend it, and one cannot help thinking that to it Lettsom was inclebted for nrany things, and, amongst others, for the art of putting in practice the Hippocratic aphorism that "the physician must not only be prepared to do what is right himself, but also to make the patient, the attendants, and the externals co-operate."

\section{STudes Medicine.}

At the end of his five years in Settle, and at the age of 20 , Lettsom, in 1766, started for London, where he was without a relation and did not know a friend. His subsequent career is so 
well epitomised in a letter he wote twonty-five vears later, that I cammot do better than transeribe it :-

$$
\text { "Isondon, December" 31st, } 1791 .
$$

"Medicine is rather" a practical than a brilliant art, and depends upon stmly ats much as genius. Poverty led mo to physic. 1 was placed with a commery apothecalry, whose fee was moderate. I had no particulal preflilection for morlicinc. I never possessed genius; my memory was hat; I nuale lictionaries and tahles of my own invention; to assist memory, I formed indexes of what I read, and by indostry acquired something. I came to London, and saw 1)r. (John) Fothergill, my ambition was inflamed, and I dared to say, london shall be my theatre; but having no more money than to carry me through the hospitals I could not attend many leetures, and upon this depended my improvement; for insteal of hearing and learning of lectures, I was compelled to learn at the bed of sicknesss. Here I saw nature, and learnt my art without the leading-strings of professors. I acpuired an early habit of behaving with lindness to the sick, and having known want, I knew how to sympathise with distress. After two years in an hospital I went to the West Indies to get assistance to bring me upon the theatre I now act. Six months abroad enabled me to visit London, Eiliuburgh, and Leyden, and ultimately to sit down in the first city; and I know not why any other person, with $£ 500$, may not do the same.

"Yours respectfully,

$$
\text { "J. C. LeTTSOM." }
$$

This is a good letter with a brave ling in it, revealing much of our Founder's character both by what it states, and also by what it omits. Lettsom does not mention in this letter that though he returned, for the first and only time in his life, to his native island to get assistance, his first action on arrival in the West Indies was to free the fifty slaves he had inheriter. Apart from these slaves, and a small portion of land, he was not possesserl of $£ 50$ in the world. "The moment I came of age," as he writes in another letter (Jamuary 20th, 1791), "I found my chief property was in slaves, and without considering of future support, I gave them freedom, and began the world without fortune, without a friend, without person, and without address." 


\section{Plictice in Iandon: Income.}

The "assistance" which he went to seek on the Island of Tortolit he himself created by starting practice there at the age of twentythree. and in the short space of fire months he amassed the surprising sim of $\mathfrak{f}^{2}, 000$. He must surely have had a keen sense of the business sitle of his profession if at this age, and as a first start, and in an insignificant West Indian Island, he could earn from his profession at the rate of $£ 1,800$ per annmm. His income later on was equally astonishing. His biographer states that by the age of forty he had acquired, and for a consideralle time maintained, the first practice as a physician in the City of London. It appears that in 1783 (at the age of 39 ) he received $£ 3,600$; in $178+£ 3,900$; in 1785 , \pm+.015 ; in $1786, \mathfrak{E}+, 500$. It is said that if, at this time, he had accepted all the fees presented to him, his receipts would have been nearly rlombled. From 1786 to 1800 (aged 42 to 56) they increased greatly: amounting to not less than between $£ 5,000$ and $£ 12,000$ ammully. When we remember Lettsom's lack of professional prestige, his comparative youth, his distinguished contemporaries, and the much greater purchasing power of money a hundred and twenty-five years ago, this goodly income-so far as my experience goes-is a higher pecuniary reward than the physician of the present day can hope for. But, if he made a goot income, it was only earned hy harel and incessant work. Thus, of this $£ 2,000$ he earned by practice at Tortola, he gave half to his mother, and, with the remaining $£ 1,000$, he determined to return to England. After a Irenderinli. sent at Erlinburgh, Paris and elsewhere, he took his Degree of Doctor of Medicine at Leyden on June 20th, 1769, with a thesis entitled "Ohservationes ad vires There pertinentes" ant commenced practice in London mnler the protection of Dr. John Fothergill. If Lettsom earnerl much money he also spent it generously; in a letter written in his 39 th year (February 18th, 1783) he writes that "with an income of $£ 5,000$ a vear I am always involved." This need not suprise us when we read that between the first day of January and the thirl week in February his clonations one year amounted to £600\%. Besides this munificence in charity, his hospitality must hare involved him in lavish expenditure. He writes that "with one lomentic or another I have about twenty-two in family" (Letter 49, Jallary 16 th, 1727). 


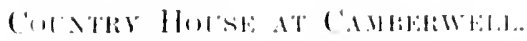

This was dombtless hetween his house in simbouk Combt, baxinghall street, in the City, and the consiberalde mansion whirh le elected in 1779 and calls "my rmal villa abont 4 miles form town" (Figs. 3 and 5, ply. $1: 3$ and 15). Jhis was (ame llill, at Camberwell, where he had five acres of garlen, 200 frnit trees, at botanical garden, a large musenm, a bibrary of le,000 volumes, an apiaty of 64 hives, walks, lawns, fountains, pouds, gromps of statmary, and an avenue called "Shakespeare's Walk," with what Pettigrew calls "an mocommonly fine statme of om immortal Dramatist" at the end of it (Fig. 4, p. 14). It is generally supposed that Camberwell owes its name to a famous well, and it has even been claimed that the identical well was situated on Dr. Lettsom? estate. ${ }^{*}$ The property, mufortumately, passed ont of his hands before his cleath, but a full rescription of it is enshrined in a volume of blank verse by the Rev. Thomas Maurice, a chamingly illustrated quarto look of 76 pages. $T$ The Medical society is the fortmate possessol of a copy of this quaint work, recently presented to it $1, y$ Mr. John H. A. Elliot, a great-grandson of Dr. Lettsom's daughter. Eliza, who married Colonel John Elliot, F.R.s. (Fellow of New College, Oxford).+ From this poem, written in the stilterl style of the period, we learn that from the smmmit of Grove Hill views could be enjoyed of Deptford, Woolwich, the "stately towers of Greenwich" ("superl, asylum of the brave"), the shipping on "the exulting tide" of the "Thames, the "sister hills" of Hampsteart and Highgate, Stanmore's " fir-clad height," and-

\section{•. . Harrow's lofty hower and spripe-erown'd brow}

Majestic frowning on the plitins below."

At Grove Hill Lettsom was in the habit of receiving visits from celehrated foreigners, and men of learning and taste. No less a character than Dr. Johnson's biographer, the immortal Boswell, was

* W'. H. Blanch, 'Ye Parish of Camberwell,' 1si5.

+ 'Grove Hill. A Descriptise Poem. By the Anthor of Indian AntinuitieThe engrarings on wood by J. Auderson, from drawings by (t. Samuel. Loudon:

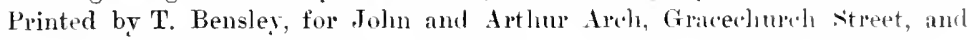
.J. Wright, Piccadilly, 1799.'

‡ 'Trans. Med. Soc. London,' rol. xli, 1!11S. 
a frequent visitor there and refer's to these Camberwell partics in some verses from which I quote the following:-

"Yet are we gay in ev'ry way,

Not minding where the joke lie:

On Saturday at bowls we play

At Camberwell with COAKLEY.

Methinks you laugh to hear but half,

The name of Dr. Letrsou :

From him of good,-talk, liquors, food,--

Ilis guest: will always get some.

And gnests has he, in er'ry degree,

Of decent estimation;

His liberal mind holds all unankind

As an extended Nation.

LetTsont we view a Quaker true,

'Tis clear' he's so in one sense:

His spirit strong, \& ever young,

Refutes pert Priestles's nonsense.

In fossils he is deep we see,

Nor knows Beasts, Fishes, Birds ill :

With plants not few, some from Pelew,

And woudrous Mangel W'urzel!

West India bred, warm heart, eool head,

The City's first Pliysician

by schemes humane,-Want, Sickness, Pain,

To aid is his ambition."

Referring to his week-ends at Grove Hill he mentions that he had "escaped depredators and robbers pretty well, not having been attacked above four times in twenty years." In parenthesis I might mention that I go through Camberwell in my weekly visits to my Clinic, and that my motor car runs me down to King's College Hospital in twenty-five minutes through the long, weary, sordid, and mean streets which have replaced the comtry lanes where his coach once rolled.

Towards the end of his life "a train of atverse circumstances, originating in the prodigality of benevolence, obliged Dr. Lettsom to part with his delightful mansion" (Pettigrew). Many of his books and tracts foumd their way to the British Inseum.

\section{Grove Hul. To-day.}

The house at Grove Hill subsequently became a school for young ladies, and there are Fellows of the society who recall attending 
patients there. A reant visit, in the complang of ome liegistrat

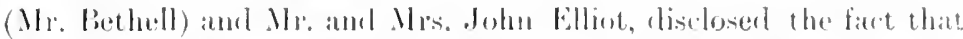

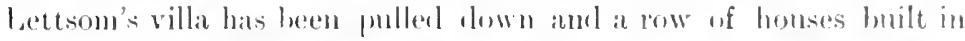

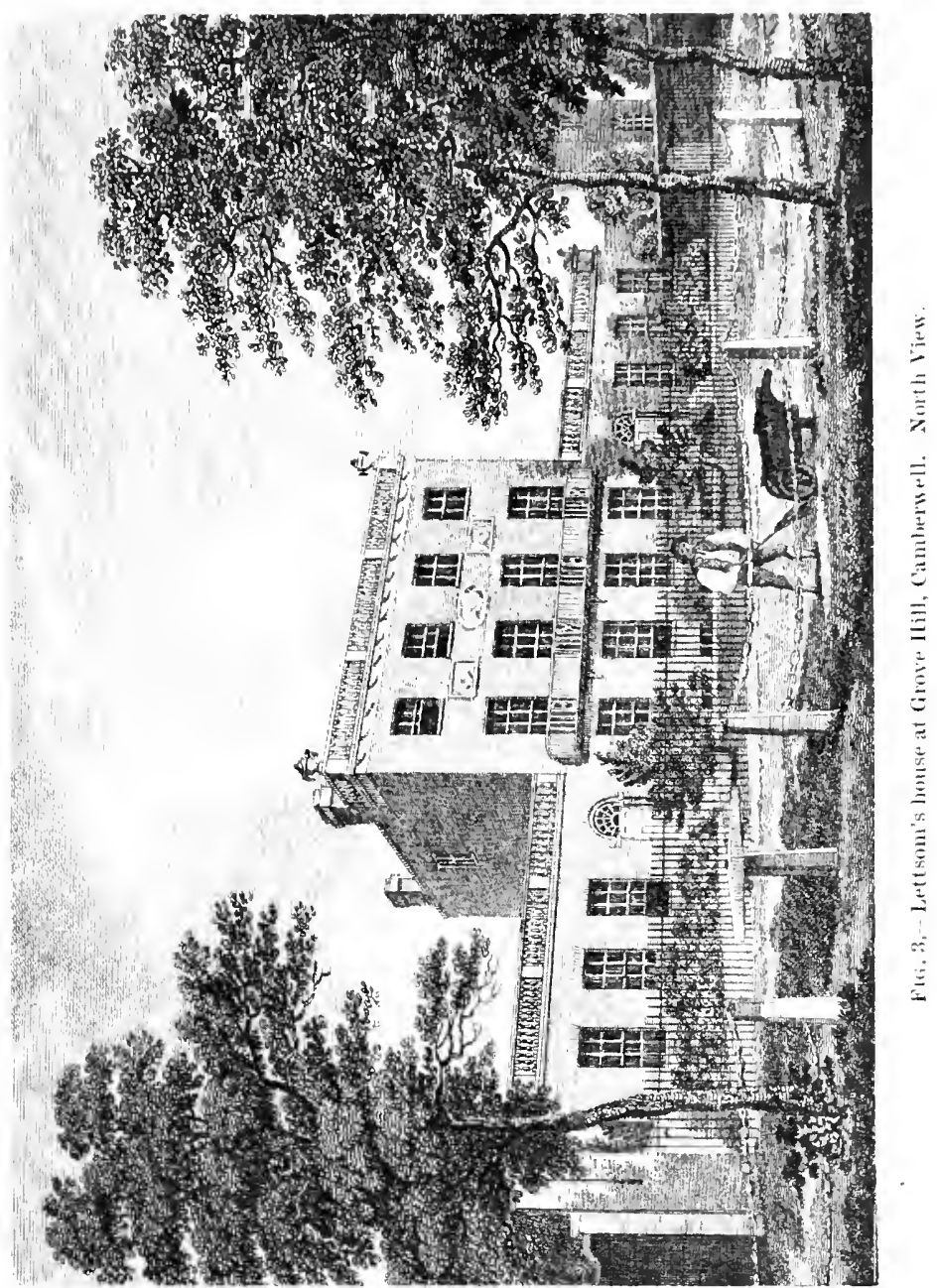

its place. However, the house and garden represented in the plan as belonging to Mr. Henry Smith and included in Lettsom's property (marked $\mathrm{T}$ in the plan, Fig. 4), still exist, and as ther appear to be 
maltered after 110 years, they give a gool idea of the dignity and charm of the "ruml retreat" where our Founder, "his spirit strong" andi ever yomng," was wont to spend his week enrls, amd dispense the generous hospitality which made his guests "gay in ev'ry" way." This property is, fortmately, in the possession of a member of onr profession, In. ('ouper Cripps, and loth house and garlen are in excellent preservation.

The Rev. T. Manrice thus apostrophises Camberwell Grove :-

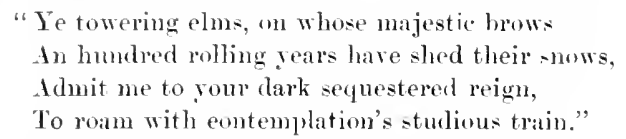

The Grove exists to-day, with its fine arenue of trees, as markerl on the plan of 1792 (Fig. 4 ), but, as we climb its straight ascent, we notice that the elms have hecome old and seanty. The dark, sequestered shade is now-a-days gratefully spread by a yomnger generation of planes, chestmuts, Lombardy poplars, oaks, limes, and acacia trees. On the left hand we notice that "Lower Springfield," "The Fountain," "Upper Springfield," "The Lawn," and "The Orchard,"-marked on the plan of Lettson's Fstate (Fig. 4)have all disappeared before the arlvance of the builder. But, on the left-hand side, there is a street which bears the name "Lettsom street," and exactly opposite to it there still stands a solitary thatch-roofed cottage, looking picturesque and forlorn, so near to grimy streets, but helping us to imagine how rustic was the retreat to which our Founder escaped - when not attacked by "depredators and robbers" during his four-mile drive from London.

Sambrook Court, his house in London, has ranished from Basinghall Street.

\section{HARD TURK: FULL LIFE.}

As I have saicl, Lettsom's good income, which he spent so generously, was earned hy constant hard work. As early as the age of twenty-three he records that he seldom prescribed for fewer than fifty, and often twice as many, patients before breakfast. When he was thirty-eight he writes (December 12th, 1782) that, "sometimes for the space of a week, I cannot command twenty minutes' leisme in my own house." A year later he writes, "since 1769 when I first settled in London I have not taken one half day's relaxation, and I cammot get to Grove Hill ahove once a fortnight." In 1791 (he was then aged 47), he observes, "diuring 


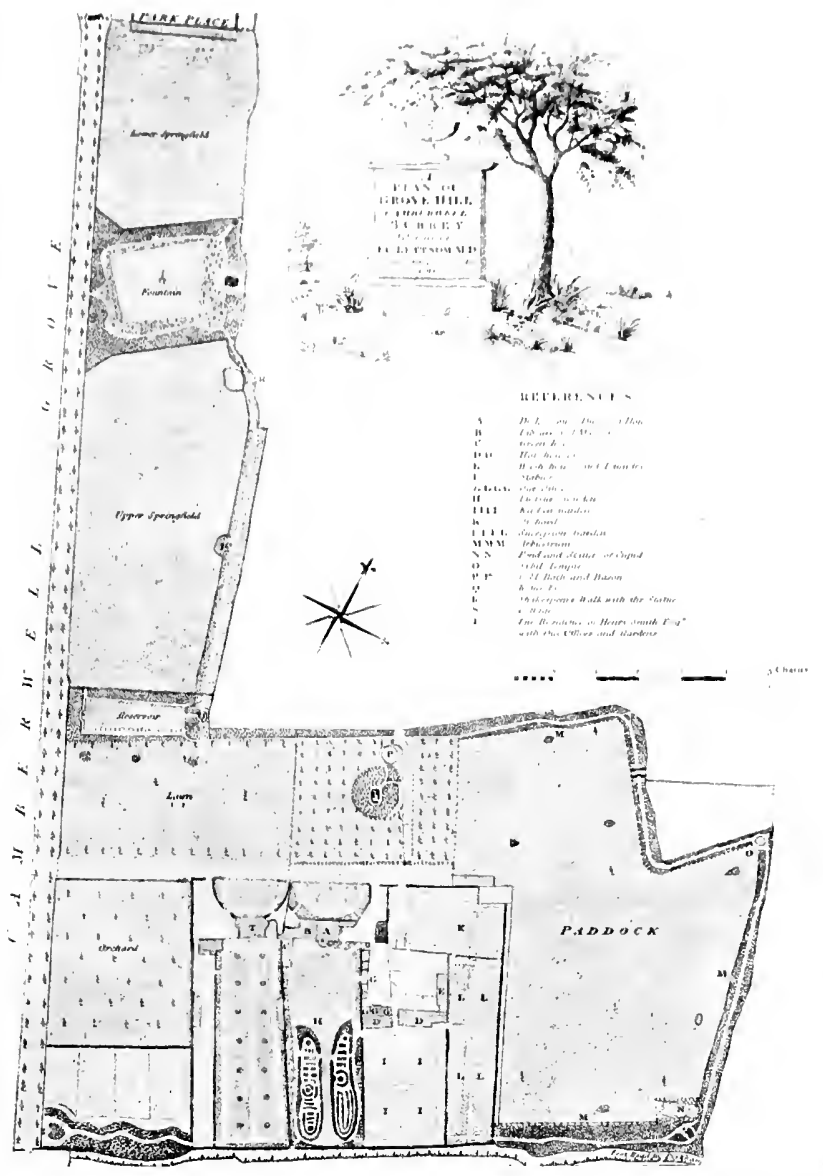

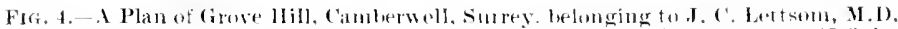
Engraved from a survey taken in 17 (32, and published on sejtember 1st, 174t, by

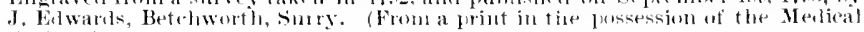
soriety.) 



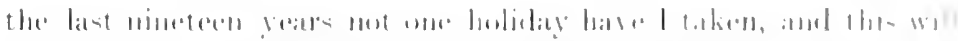

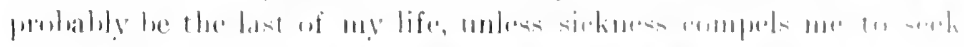

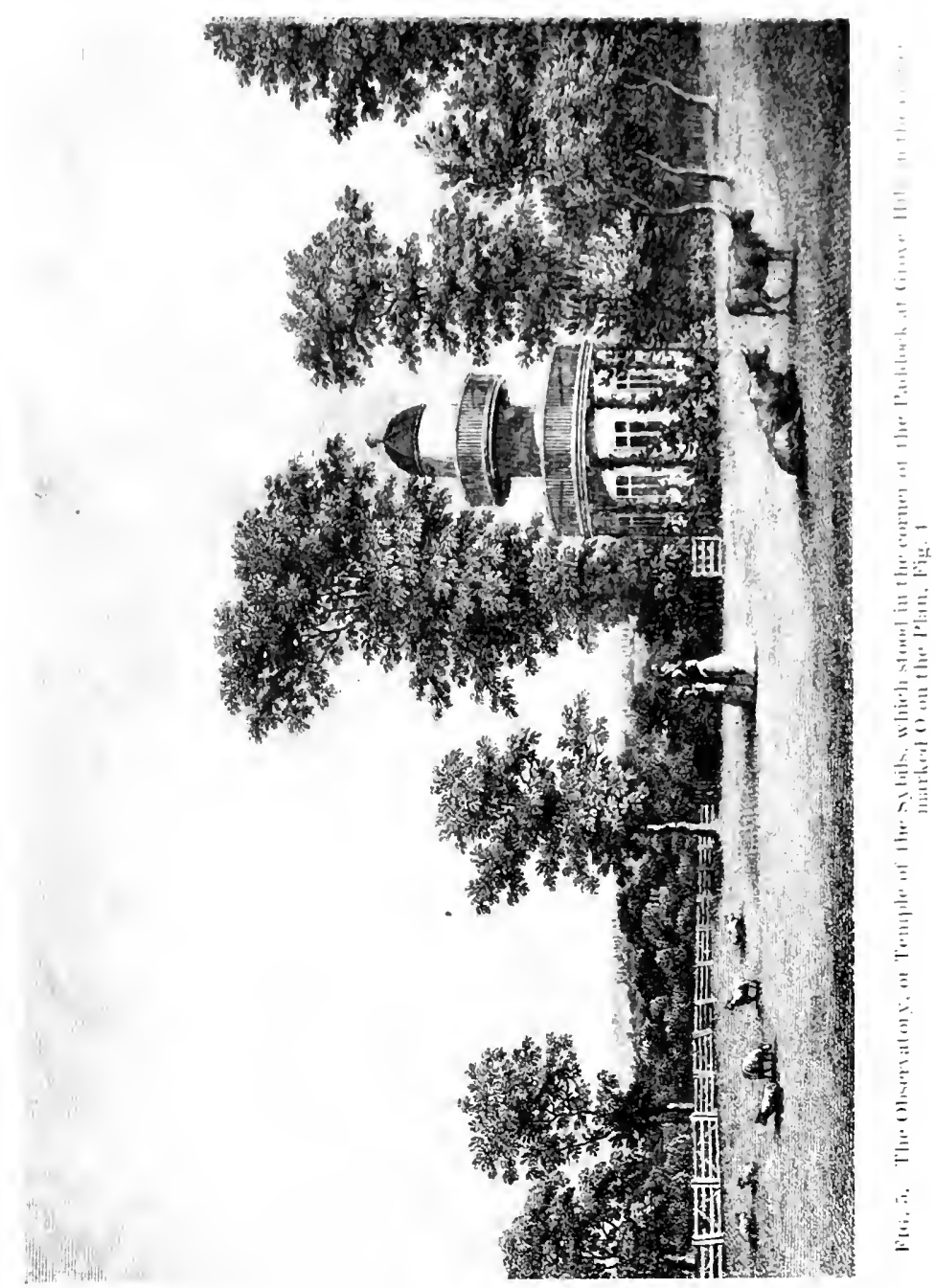

leisure." The "holiday" here referred to consisted in tratelling by coach to Margate, spending two hours on important busines there, and returning the same day, $1+4$ miles in the day and night. In another letter he records that his practice "bard not suffered 
him to sleep in his own bed for thirteen following nights," and he evidently spent mueh, not only of his days but of his nights, in his travelling coach, for one correspontent (February Sth, 1783), reproached him for "converting his earriage into a dormitory and a suttling-booth." His earriage served him for still another purpose; he lived in the dars when letter-writing was an art; he was a voluminous writer, at times keeping up frequent communication with 200 correspondents, and ret nearly all his letter-writing was done in his carriage. He writes: "As I live in $\mathrm{my}$ carriage, seldom having less than three pair of horses a day, and neglecting my meals, except once a week that I dine with my wife, I have some time to preserve my correspondence, having always in the earriage pen, ink and paper, to amuse myself if I do not amuse my correspondents." * In spite of this he records in his seventieth year that, owing to his large correspondence, he was seldom in bed hefore one in the noming (March $26 \mathrm{th}, 1814$ ). When we reeall the condition of the roads in the 18 th century, the pace at which his coach must sometimes have travelled, and the non-invention of stylographic pens, it is astonishing to glance at the number, length, and completeness of the letters which have been preserved, and to read, in a letter dated September 25th, 1804, that "my professional duties incessantly occupy me, and compel me to write all my essays in my carriage."

\section{Favourite Holiday.}

The fullness of his life may also be judged from a record of his farourite holiday. It is described in the following words by his biographer, Pettigrew :-

"The only relaxation, if such it may be called, that Dr. Lettsom ever permitted himself to enjoy was an annual visit to Margate, to attend the anniversary of the Institution (i.e., the Sea Bathing Infirmary). For this journey he usually alloted 72 hours. $\mathrm{He}$ left town on the Saturday sufficiently early to get to Margate in time to hear the charity-sermon preached on the Sunday morning on lehalf of the Institution. The remainder of the day he spent in risiting a few families in the town, at Ramsgate, and at Broadstairs. On Monday he examined every patient in the Infirmary, attended

* Letter 111, september 3rd, 1795, in 'Selections from the Medical Papers and Correspondence of the late John Coakles Lettsom.' By Thomas John Pettigrew, London, 1S17. 


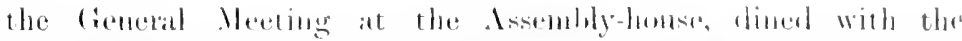
Governors and friemls of the C'harity, amb at soren welock set ont for Lomblon, where he arrived on the fleselay moming. Thi excursion always allorelerl the Ineter very great satisfaction." No loating week-end this for the husiest physician in lomdon!

On the oceasion of another of his visits he tells us that he sailoul from Billingsgate in the parket at four o'clock on the aftermom of the gsth and got to Margate at nine on the 29th. He "left Margate at nime in the evening of the 30 th and arrived in Lomdon ly Chaises at ten o'clock in the moming." I single night in a hed, sandwicherl between two stremous diess, precerled by one night tossing down the river in a packet, and followed ly a third night of thirtecu hours' jolting in post-chaises, was not harl going for a man of 69: (1)ialy, Angust 28th-30th, 1ஃ13.)*

\section{MNNHWL INTERESTS.}

If all these strenuons days and nights hart been devoterl sulely to his extensive practice, we should not he surprised. But his varied interests and self-imposed duties were spread over a large variety of suljects, and he rendered important pulblic services as a philanthropist. In 1770 lie founded the (ieneral Dispensary in Alelersgate Street (the first of its kind in London); he establisherl the Sea Bathing Infirmary at Margate; he was one of the Founders of our own Society; he was an active member and a lecturer of the Philosophical Society ; he was one of the Founder's of the Royal Humane Society; he was a friend and supporter of Elward Jemner, and an active supporter of the recently introduced vaccination for small-pox; the reform of prisons was responsible for his friendship and admiration for John Howard, and the amelioration of the condition of the poor and helpless was his constant care. He was the first man to introdnce into England the mangel wurzel, as is jestingly referred to in the rerses I have quoted, and he always kept up his interest in hotany, agrienlture, and fossils. He wrote a hook called the 'Naturalist's Comprnion,' which ran through three editions, two editions of 1,500 heing sold within 12 months (Letter 109, December 1st, 1n04). He pointed out the use of birds-even crows - and of moles, in Nature's economy, and

* Eor a reading of Lettsom's manuscript Diary I am indebted to hi. great. great.grandion, Mr. jom H. A. Elliot. 
plearled for their preservation (Letter 1:37, June 22nd, 1812). He anticipated our cult of the open window and the researches of Leonard Hill, when he wrote his 'Essay on the Effects of Heated and Stagnant Air' (see Letter 193, Septemler 17th, 1772).

Soup kitchens met with his entire approval; the mamer of preparing lifferent kinds of soups is minutely noted in his pamphlet, and the lest receipts are given for various articles of diet. Alas, that, after some 125 year's, our somps should still be execrable and our cuisine a bye-worl amongst the nations! In 1798 he publishert a tract entitled 'Hints Respecting the Effects of Hart Drinking.' He directed attention to bee-hives, "as appendages hoth of ormament and utility to the gardens alont the metropolis." He calculated that, within 20 miles of London, no less than 50,000 bee-hives might be maintained, which, upon an average, would produce as many guineas ammally in honey and wax, two very important articles of domestic use. In 1795 he wrote a tract on 'Hints Respecting the Chlorosis of Boarding Schools,' with advice as to games, diet, clothes, cleanliness, etc. He was greatly interested in the history of medicine. The Kadterrercertungsanstalt in Germany, about which there has recently been some commotion in our Press, wonld appear, from a letter of Lettsom's, to have been anticipated loy 124 years. In 1793 he writes: "A friend of mine has lately discovered the art of changing human flesh, particularly the fleshy part, into spermaceti candles. This is not a fable. He means to light mp the large room of the Royal society with the leg of a man. I advised him to go to the swamps of Dunkirk, to Lyons, Weissemberg, La Tendée, or Tonlon, where he might find materials sufticient to supersede all the tallow of Rinsia. If this project succeed, we shall refine on the custom of the ancients in burning their dead. We may hurn our friends over a supper or a pipe. This scheme may puzzle the Materialists about collecting the remains against the last day. My friend has promised me some human candiles, but my wife will not suffer them to be burnt" (Letter 95, Octoher 15th, 1793). He legins this same letter by saying, "My son is just returned from Güttingen, after nearly a two years' absence," but there is no indication as to whether the friend who had invented this new sort of human spermaceti candle was a Boche or a Briton!

In 1 , 01 he published three sro volumes of collected essays under the title of 'Hints Designed to Promote Beneficence, Temperance, 
and Mertical Science, ${ }^{*}$ and in these are fomul essay's on such varied subjects als Poverly, Dischargerl l'lisoners, l'rostitution, lufertions Fevers, a Simmeritan Socicty, ('rimes and P'mishments, Wills and 'Testaments, Lying-in Charities, the Ieaf and Dmmb, Village Societies, the Blind, a Society for Promoting Useful literature, Ilints to Masters and Mistresses, lieligions Persecntion, Ihnmane rocieties for the liecorery of lhowned P'ersoms, the Cow-pock, Carrl l'arties, Sunday Schools, the I'bilinthropic Soeiety, Dispensaries, Ilychophobia, Seit-bathing Infirmaries, and a Sisbstitute for Wheat Bread. In 1815 he printed a Sketch of the Life and character of his friemd Dr. Rinsh, entitled "Recollections of Dr. Rinsh."

Lettsom's works have heen divided into thee classes: -
I. Medical and scientific.
II. Biographical.
III. Popmlar and Philauthropic.

Amongst the first we find 'Reflections on the General Treatment and Cure of Fevers,' in the second class 'The Natural History of the Tea Tree with Observations on its Merlical Qnalities,' while in the third are found his Lectures on Medicine and Materia Medica with "Practice of Physick." The Dictionary of National Piography gives a list of some 40 or 50 contributions to literature

\section{Sibstitetes for Wheatex Bread in Wal The ix 1800.}

Amongst his manifold interests, the important matter of bread supply-including the social, economic, and national sides of the question-did not escape Lettsom's attention. One gathers from his writings that the price of the quartern loaf in $177+$ was $8 /$, lut by 1800 we find him writing: "At present our quartern loaf is 1.. 6el., a sum truly oppressive to the poor" (Letter 99, July 28th, 1s00). With our present day quartern loaf at only $9 d$., after three years of world war, our population may take courage by seeing what our forefathers had to endure in the Napoleonic struggles. In 1774 Lettsom, amongst his numerous essays, printed one entitled, "Hints respeeting a Substitute for Wheat Bread," and this he republished in 1801 in the 3rd volume of his 'Hints and Essays.' The substitute he warmly recommends is the fine flour of Indian

* Loudon: Printed by and for Nichols, Son and Bentles, Red Lion Passage, Eleet street. 
corn, to be mixed with that of wheat in equal proportion. He adıls that, "if rightly managed, the coloul will be about the same as the standard wheaten bread, and about $2 d$. in the quartern loaf cheaper than the fine wheaten, when that may be at $8 \%$. per quartern." After insisting on the great nutritive value and the agreeable sweet Harour of maize, he writes: "Siome, indeed. do not so easily reconcile themselves to it, which often arises from the mismanagement of grinding the corn or baking the brearl." The bakers, he directs, have not acquired the best method of mixing and preparing it with wheat-flour, and as to the grinding, he aulvises that the mill-stones should first be set so wide as but just to burst the thick or farinaceous part of the grain, which should then he passed through a sieve, so as to separate the part of the interior erlge of the grain, composed of a ligneous spongy substance, the midclle of which is of a dark brown colour, and of a bitter taste. which, if ground into the flour, gives it a disagreeable flarour. When this deleterious part has been separated on the sieve, the remainder should be ground with the stones set so as to render it sufficiently fine. "By this precaution," he adds, "the flour is as white as that of the finest wheat, and full as pleasant to eat; it posiesses the peculial quality of preserving the bread, made from at mixture of it, in a moist state for many days, which, at least in dry weather, is no inconsiderable advantage." He expatlates on the way in which the adoption of this "substitnte" would release our agrientural lands for other important cultivation. Lettsom also snggested the use of potatoes as a partial substitute for bread, and recommends the use of one-fourth of potatoes with the remainder of flour, as comprising the most pleasant and wholesome bread that can be taken. He points ont that if a little ground rice is added, the lrear is preventer from crumbling, a matter of consequence in a large family.

\section{The Making of Polindme.}

In this sime essay on "A substitute for Wheaten Bread," he describes how prridge should be mate. The directions are so detailerl, clear, and concise that I camnot refrain from giving it as an example of the scrupulous care he took in his writings and as showing the intimate personal knowledge he had of such small, but highly important, domestic matters. I give his recipe with the 
greater willingness, since I know myself that it is the hast methoul, and will result in a very moch better tish than one sometimes meets with in England :

Letsom describes the proeess ats applied to Indian meal (maize), lut it is quite the correct way of conking sicoteh oatmeal porrielge. Ile writes as follows:-

"The eheapest and most alvantageous method of using Indian (orm as fool is by making the flour of it into hasty pudding, in a mamer very similar to water-pottage, a fool made of oatmeal in the North of England and in Scotland. A quantity of water, proportioned to the yuantity of hasty pudding intended to be made, is put over the tire in an open inon pot or kettle, and, a proper quantity of salt for seasoning the purlding being previonsly clissolved in the water, Indian meal is stirren into it by little and little with a wooden spoon with a long handle, while the water goes on to be heated and male to boil, great care heing taken to put in the meal ly very small qumtities, and by sifting, it slowly through the fingers of the left hand, and stiming the water about very briskly at the same time with the wooden spoon with the right hand to mix the meal with the water in such a mamner as to prevent lumps being formed. The meal should be added so slowly that when the water is brought to boil the mass should not be thicker than watergrutel, and half an hom more at least shonld the employerl to add the additional quantity of meal neeessary for bringing the pucting to be of the proper consisteney, during which time it should be stirred about continually, and kept constantly boiling. It should be of a consistence to suspend a spoon upright. It may he eaten with milk, or with butter, sugar, or molasses."

\section{American Frtendoships.}

A reference to his many honours gives good evidence of the general opinion entertained respecting the literary, philosophical aud henerolent waracter and talents of Lettsom ( 1.40$)$. It will be observed that many of them came from America, a part of the world where he had numeroms friends and was highly respected. Inleed, in his time, no student from America was thought properly equipped unless provicled with letters of recommendation or intro duction to Lettsom. So great was their faith in his judgment, that the selection and purchase of books for the Pemsylvania Hospital was entrusted to him. A rich tract of land, the property of his 
friend Dr. Benjamin Rush, upon Sugar Creek, a stream which empties itself into the north-east branch of the river Susquehamna bears his name, or at least rlid, when his Memoirs were published by T. .T. Pettigrew in $1 \$ 17$ (rol. i, p. 101).* (Fig. 6.)

He was the first to send.Jenner's vaceine lymph across the Atlantic, consigning it to the care of his friend Dr. Waterhouse, Professor of Medicine in the University of Cambrirlge, Massachusetts.

He sent the seeds of the mangel wurzel to Dr. Benjamin Rush, of Philadelphia, who acknowledged them as follows: "Many thanks to ron for the seeds of the mangel wurzel. I have distributed them extensively. To our great and good Virginian farmer, General Washington, I have sent the largest number of them " (Letter 205, May 4th, $1788)$.

\section{Associlation with Celebritted People.}

But his large practice and all these multifarious occupations dicl not exhanst Lettsom's houndless activity. His varions interests and his general culture, added to his hospitable and cheerful character, bronght him into contact with many of the most celebrated people of his generation,-_a time when the renaissance of English art and literature was in full flower. Although he was born, lrought up, and lived a Quaker he was-particularly for that period--remarkably free from all religions bigotry. In spite of the tenets of his sect he was gazetted Physician to the Camberwell Volunteer Infantry in September, 1803, and although he writes, "as a Quaker I could not adopt a military character," yet, he exclaims, "May I fall by the sword rather than live to see this free country the domain of a Corsican murderer and usurper!" (April 20tl, 1r05.) We might commend this generous sentiment of 1805 in a Quaker physician, agerl 60 , to the conscientious objectors of our own day. Dr. Lettsom, though ready to die l,y the sword, rleclined, as a Quaker, to wear one. When referring in a letter to George III he writes: "The King has always theen

* Through the great kinduess of Prof. W. W. Keen, of Philadelphia, I have been able to trace this tract of land, and Mr. Thomas L. Montgomery, of the Pemnsylrania State Library, IIarrisburg, has been good enough to supply a "opy of the maje reproduced in Fig. 6. Ife points out that the plots in this plan were not owned by Dr. Benjamin Rnsh,--the hero physician at the time of the plague in Philadelphia in 1793,--but by his son, Richard, Attorney General, afterwards Secretary of the Treasury, and at one time Minister to England. He ilso informs me that there is no mention of the two names,--Letsome and Fothergill,--in the molern maps nor in the Gazetteer. 


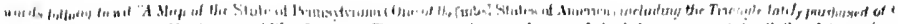

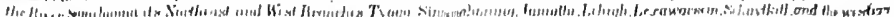

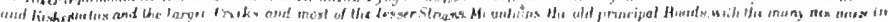

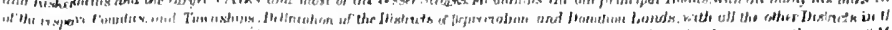

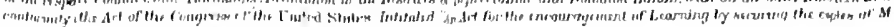

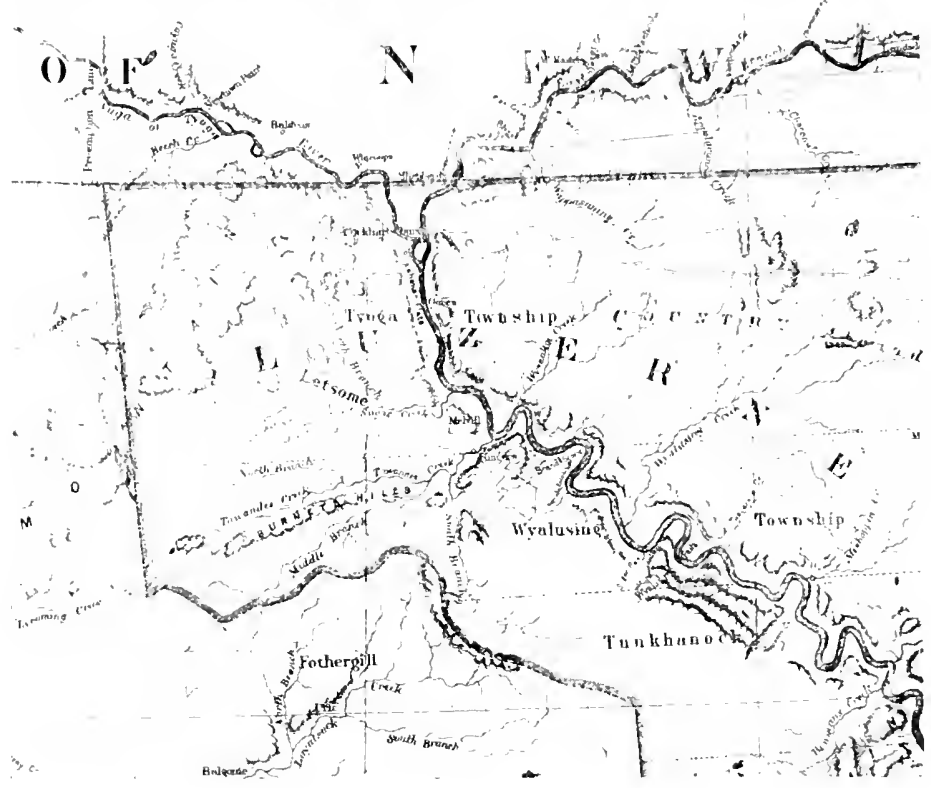

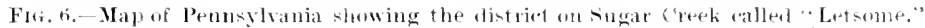

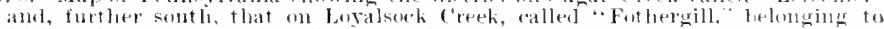

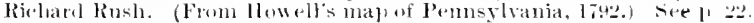





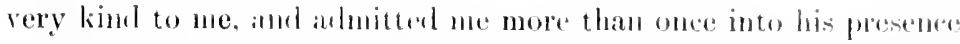

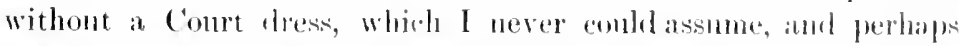
I am the only person who ever kissent his hand mopewdered and

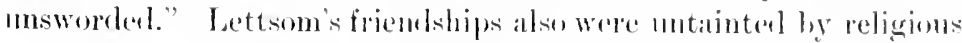
Halrowness: imfeed, he expresses his partiality for the socioty of the Clergy of the linglish C'mureh, beeanse, as he saty, "thry atro a learned and improved part of the community." "The religion of a Qualier," lue aldis, "as far as l know, is ats expansive ats tha air ; at least 1 rolertain no partialitice for seet" (Ietter 109, Decenber List, 1s04). With one of them, the lies. J. l'hmotre, he kept up a steady eorrespondence for ten years. So, in regarl to the theatre, he writes as follows, on December 1st, 17st: "Abont fourteen years ago I went to see Garrick in King Leur, and never since have been at any theatre till the present time; it is not fuite consistent with our religrions system, hut I confess I like to see perfection in every species of art, and this wonderful woman, Mrs. Sillons, heing a subject of miversal admiration, I ventured, against ecclesiastical orthodoxy, to see her in Zaru. It is astonishing with what powers of nature and passion she call place herself in the tender movements of the heart. She spealis as if she suffered all the woes she describes, lnt she speaks most powerfully to the soul when she is silent: her features, her attitudes, give utterance to that language which melts the heart, and interests imagination. She is a fine figure; she is just that merlimm which has softness without grossness, and tender expression without langnor." This catholicity in his tastes and friendships is further illustrated by the following letter, thanking Sir Mordaunt Martin for the present of a turkey (April 27th, 1792): "Accept my thanks for the gigantic turkey, which faced with gallantry and undismay a gromp of different nations and sects. I had Sir John Peter, Consul at Ostend, Professor Blımenbach from Göttingen, liesides a Scotchman, an Irishman, a Dane, an American, a West Intian, a Papist, a Presbyterian, a Quaker, a No Religion, a Sandemanian, and a staunch Churchman, who all agreed in one Creed, that the deacl Philistine or Titan merited the united benediction. It was an entertainment that afforded me mueh gratification. Happy sacrifice to the appetite of man, that thon shouldst effect more concord amongst different nations and sects, than even reason, the prondest and sublimest of all men's gifts!" This sociable and cosmopolitan trait in his character is noter by his biographer who writes-" The 
muiversality of his acyuaintance, his extensive practice as a physician, his unbounded philinthropy, and his comection with public institutions for the promotion of medical, philosophical, literary, and benevolent pursuits, introrluced him to the knowledge of all classes of society and obtained for him universal esteem and admiration." lettsom was associated with some of the most celebrated men of his time, an age rich in historical persomalities. We have seen how he was freepnently received by King George III; he records his impressions of hearing Fitt and Fox speak in the Honse of Commons, he corresponded with "General Washington of America," Dr. Rush of Philarlelphia, Benjamin Franklin, Elrismus Darwin, Baron Haller; Sir Charles Limme (Limnæus) wrote to him in Latin; le studied muler IMr. Akenside (the author of the 'Pleasures of Imagination,' whom he fouml "the most supercilions and unfeeling I'hysician he had hitherto known"); amongst the Founders of the Royal Humane society $(17 i t)$ he came in contact with Dr. Oliver Goldsmith, Dr. Iteberten and William Fox: he interrogated George Bidder, the remarkible eight-year-old boy who lived in St. Bartholomew Close, who could not write and scircely reard and ret made long arithmetical calculations (May 17th, 1815); he came across oamma Simtheott and attended Lady Huntingalon; he met Braham at musical parties, and he dined with Wilkes, Boswell, and "lee the Aneriean" (February sth, 178s); he knew the celebrated Larly Hamilton and wats very grateful to her for her kindness to his son wher visiting Naples; Sir Willian Hamilton, "loaded with year's and honours" visited him at Grove Hill; it is not clear if he ever" met Lord Nelson, lut the great sailor expressed his "respect and atmiration" over several of the letters written ly Lettsom to Nelson's neighbour in Norfolk, Sir M. Martin (he of the Titanic turkey); amongst his intimate friends were Edward Jenner, of Berkeley, in (rloncestershire, and Balington, who nearly invented the litryngoscope (see p. 61).

\section{JI: SAMEEL JOHXSON INI BOSWEL.}

Boswell, whose verses I have already quoted, was a frequent visitor at Grove Hill, and Dr. Samuel Johnson must often have called in

* Lettsom writes that he had also been acquainted with Lady Ifamilton "when Miss Hunt" (Letter 122, Jume 3ril, 18(15), hut this is doubtless a slip of the pen for "Min- Hart," as Emmal Hart wa- hel name in her early and clondy days. 
there on his waly to teit with Mrs. Tharale, at Streatham. Lettsom evidently knew him well, and gives us the following expnisite pen picture of hin (.lammary 13th, 1785):- "The late Dr. Johnson was a pions num : altarhed, I confers, to estahlished system, hut it wats from principle. In company I neither fomd him anstere nor clogmitical; he wals cartidinly not polite, lut he was not rude; he was fimilian with sutable complany, hat his langlinge in conversation wats sententions: he was sometines jocular, but you felt as if you were playing with a lion's paw. His hody wals large, his features strong, his fate sealleed and furrowed with the scrofulat he had at heavy louk. hut when he spoke, it was like lightening over a dark cloud. With a capateionsness of mind, and some inequalities in it, like his face, he resembled at Colossus, which, like that at Rhorles, embraced the whole sea of literature, atfording awe and distance rather than esteem and social friendships; and from some of his writings one may discern a steruness from his disilppointment rather than from philosophy. His Ratsselas, Prince of Abyssinia, was perhap his own picture, and it inculeates apathy to the world, rather than happiness in it. Upon the whole, he seems not to have heen a happy man; his religion was rigid rather than social ; and his mind warped by system rather than humanised by virtue and truth. But who is perfect?"

lettsom's conviviality is ilustrated by the following description of his meeting with the renowned Admiral Sir Willim Sydney Snith (176t-18t0), at the house of his friend and patient, Abraham Goldsmid :- "At Goldsmicl's ball I met a man I had wished mueh to know, Sir Sydney Smith, so I told him, and he assured me he had a similar menclunt. We ate a sandwich together, and then hola-nob'd our glasses of porter, and at half-past one in the morning 1 left him dancing with a Jewess" (Jannary 3rd, 1805). This cheery picture of a Quaker in his 61st year, the leading physician in full practice in London, fully hears out his own statement that "my" spirits carry me through a succession of employments with facility" (Decemher 1:th, 178\%).

\section{LetThon's strandols Life.}

Certainly his constant "succession of employments," his enormous practice by day and by night, his long coach journeys, his multi farious social engagements, his hospitable entertainments, the care of his garden, his voluminous correspondence and his extensive 
publications, fill one with wonder. When we recollect that this fuil life was lived withont onr morlern airls to despatch in the way of secretarjes and stenographers, telephones and telegrams, railways and motor ears, one is the more astonished. Evidently the strennons life was not invented l,y Theodore Rooserelt, and a physician of the 18th century conld work as hard as any hustler of our time to earn neurasthenia and nerrous prostration. We are not surprised that a friend wrote to him (Letter is, Fehruary 8 th, 1783) that "the perpetnal vortex and whirl in which yon live really amazes me," and pertinently asked, on hearing of Lettsom's visiting 50 to 100 patients a day, "Is it possible that, with all your learning, sagacity ant acnteness, you can, on such a superficial view and inquiry, be thoroughly instructed in all the circumstances of your patients' cases and constitutions?" His friends preacherl (Letter 8, March 5th, 1783), "some repose aurl some relaxation from that perpetual tension both of mind and hody" which goaded him "to persist in such an incessant hury and-whirl." And again, "Let me seriously advise you, my friend, for the sake of your health, to relinquish your nocturnal luculritions and your convivialities. Go to bed with your wife and family at 11 o'clock and rise every morning as early as Mr. Hales" (Letter 10, March 18th, 1783). 'Two years later (Letter 45, Norember 25 th, 1755$)$, the same candirl acquaintance writes: * Upon my word, my goorl friend, your sitnation is truly deplorable and claims compassion. Neither night nor day, nor any change of season allows you a moment's repose, incessantly employed in rattling along the streets and highways, on a long trot, hearing dismal narratives of disease and despondency, prescribing for the sick, relieving the wants of others by your benevolence, compusing works for the benefit of the public, superintending the progress of the press and carrying on an extensive correspondence-even compelled to write in your carriage." These jobations respecting "the whirlwinl in which I live and move" Lettsom accepted with great goml natmre, expressed "a decreasing ardour after medical employment and a thirst for rural retreat" (Letter :3), determined "on sleeping every night out of town," "pritting night business and long night journeys" (Letter 75, Narch 13th, 1790), and yet, some 14 years later, we find he is "rarely" at Camberwell, but "usually dines there every Sunday with a party of select friends and now and then sleeps there" (Letter 109, December 1st, 1804). Although he 
deplones that his "pontessional doties obliged him to momin a denizen of the metropolis," yet he was ahle to hob-il-mels at halls at half-past one in the morming and take his week-end rest ly a rosh to Mlargate anml back:

The fact is, lattsom lored his life and revelled in his werwork. "I love my profession," he writes, "I live with my patients in tho most frank sociality, and I fancy they love rather than feal me." And, again, "medical husiness is not my plagne hut my pleasure" (Letter 4, Decomber 12th, 1752). In his fifty-first year he writes: "This is the highest ant most divine profession, that ean cngage human intellect. I have attended eighty-two thousand patients. and what ean equal the dignity of having so many lives entrusted to your decision! What more divine, than to sooth the afflicterl, and soften agony! What more sublime than to restore to life the victim of disease! I envy not the prince on the throme, nor the sultan in his harem, whilst I enjoy the contirlence of the sick chamber and the blessing of the restored. I love my profession, perhaps too much. It loves me, and I have no oljection to die in the chamber of malady, provided I can mitigate it in a fellow creature" (Letter 111, Neptember 3rd, 1795). Inleed, Lettsom's life was an illustration of the saying, "Si l'amour de la médecine fait le savant, e'est l'amour du malade qui fait le mólecin." He also believed in raried interests and in the virtue of enjoyment." Writing on distractions and hoblies, he says (Letter +7 , May 28 th, 1786): "For my part, it ill hehoves me to censure, who keep a whole stud of race-hobbies. If I had leisure, I would take up a defence of them under proper hits and bridles. They are the best remedies I know of for that dangerous disease called emmi, which is an introduetion to every other malady of the mind. If money, by increasing and hoarding it, eonferred any mental good, it would be wrong to increase intellectual pleasures at the expense of the Summum. Bonum; but, if hoarding it be proved the Summum Fitimm, let us, dear friend, oceasionally trot, and even gallop, our intellectual hobbies.

* "In thus comecting a diversity of ohjects, our investigations are accelerated, and our pereeptions expanded; the mind not onlı becomes more vigorous, but elegant from the frequent and extensive use of its porrers; what it hath begum, it will have the sagaeity to finish; and what perfected, the spirit to refine. For want of this liberal and rigorous cultivation of the arts, the mind has gradually become enerrated, and has relinquished that sublimity and refinement which it had once acquired" (J. C. Lettsom, "History of the Origin of Medicine,' London, 1578, Introduction, p. 8). 
Who will thank us for dying rich? Not those who get hold of our scrapings. And pray who earns his money with more solieitude than a physician? Who, therefore, has a greater moral right to exchange care for pleasure? especially when those pleasures are the gratification of intelleet. This rational system of conduet is not beneath the wisest and best of us; let us therefore keep our hobbies and ride them too." In these words we seem to hear, echoing down the centuries, the philosophic advice of shakespeare tr. -

"frame your mind to mirtl and merriment

Which bars a thousand harms and lengthens Infe."

The Teming of the shere, Induction. sc. 2.

inrl not

"To tie my treasure mp in silken bag-

To please the fool and death.'

Pericles, iil, 2.

A sturly of his career convinces me that Lettsom threw himself into his protession from lore of the practice of it, and into his philanthropic works from, as his hiographer states, "henerolence and real goodness of heart." Certain it is that he had no need to work so hard for mere money, for when he was only 26 years of age, he married the daughter of a wealthy tin-plate worker, resident in Cannon Street, "and $1, y$ this marriage acquired a very considerable fortune." And he was neither self-indulgent, extravagant, nor niggardly, for" he tells a friend "that with an income of many thousanls a year from my profession I cannot grow rich." Although he "enjoyed"-as the nsual phrase puts it-the most fashionable practice in London, yet he realised fully the fickleness of the public, their ignorance in matters merlical, and the eraze for quackery even amongst the upper and cultured elasses. In a letter to a medical friend in Dorchester he writes: "Among the people of fashion in London, quackery is cultivated. Can one wonder at lying advertisements, when it is known that Garrick, Lord Lonsdale, and the Bishop, of London were for awhile the patients of Myershach.* These were men of sense; but what is the intellectual state of our nolility? Perpetually enslaved by the novelty of fashion, however mitre, they acquire a constitutional propensity to imitation in ererything; and leave their physician as they quit an old coat" (Letter :.2, August. 1787).

* I wall known fierman quack of the period. 


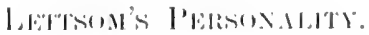

What mammer of man was letetson, and low dicl he mamage to live this stremuons life mut he was orer three score years and ten? His colleague and hiographer, 'Thomas Joseph l'ettigrew, thus deseribes his "persom and habits": "Tle was of a tall, delicate, extenuated structure; his face was very strongly furrowerl, and his skin was of a dirk yellow tint. He was remarkilhy neat in his dress, which was miformly the same and construeted after the manner (though not with the ntmost precision) of the religious society to which he belonged. II. was astonishingly active, even until the commencement of his last illness. He nsmally walkerl to attend a portion of his patients for two or three hours in the morning, after which he would take his carriage to visit the remainder. He enjoyed a very good state of health, though suljeet to a congh in the winter months, for which he usually hled and applied a blister, but he never confined himself on this

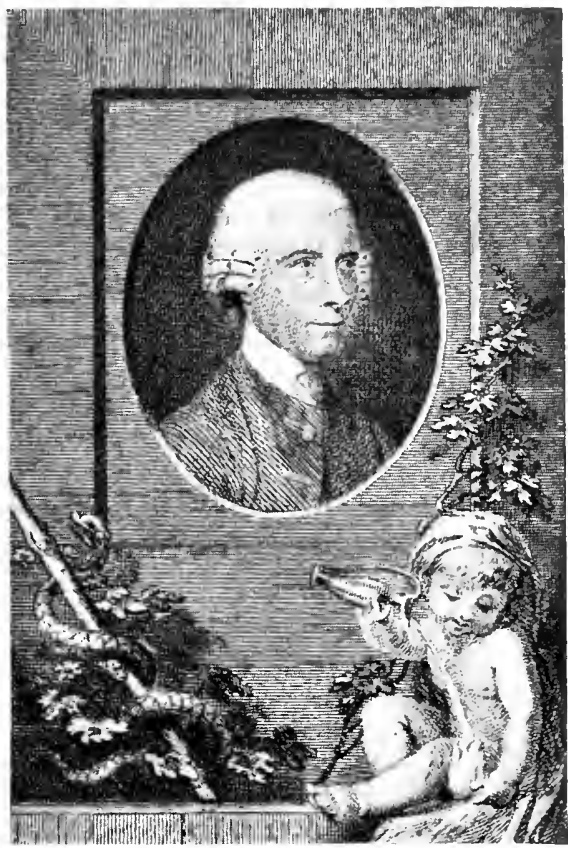

Fiti. i.-John Coakley Lettsom.

(From a juint kindly lent by Mr. John IL. A. Flliot.) account. His temperate habits conduced to the enjoyment of health. He seldom exceeded taking more than three or for glasses of wine after dinner, which meal he usually ate with a keen appetite. Coffece was his favourite beverage, which, as he was aceustomed to sit up frequently during balf the night, to answer his numerous correspondents, and pursue his literary engagements, very much refresherl him. Before going to rest, he uniformly bathed his 
limb in whl water, and in the morning aspersert the whole of his body with the same. To this practice he attributed the (x) llent state of health he possesserl. The equable temper he preservel, no doul,t, contributed materially to this desirable end; for his own benevolent heart imprelled him to construe with indulgence the actions of others, however unfavourable they might appean: for he was never known to speak ill, even of his own inveterate enemies. He was the miform pacificator of all differences amongst his friends, which came to his knowledge, and he very rarely failed in effecting an adjustment of then. His friendship, as might be expected, corresponded with the rest ot his disposition and character; for, although he was most srinfulowely tardy in forming attachments, experience, unfortumately, hanl tanght him the fallacy of confiding too hastily on meretricious appearances: but, when once assurerl of the correctness of his judgment, he proved a firm and underiating friend. His conversation was very sprightly, and enlivened with a variety of curious anectotes. $\therefore$ perfectly conld he adapt himself to the habits of all kinds of anciety, that he was as fit a companion for the young as for the aged; anl each received the benefit of his instructive remarks, while the smile of benignity beamed upon his conntenance, and the warm strain of benevolence played round his heart." This description of our Founder's appearance confirms the impressions we receive from the engravings aceompanying this biography, and the paintings on the walls of this room. The purtrait on the west wall is less worthy than the celehrated group on the east wall by Samnel Medley, which shows Lettsom and the original Fellows of the Medical society. His personality is bronght nore before us if we remember that he was "mpowdered and minworled," that he wore a bol, wig. and that his reference to himself as "a volatile Creole" may explain his yellow complexion. ( $\%$. Figs. 1 and 7 , and Fig. 16, ficing p. 54).

\section{METHOD OF WORK.}

This being Lettsom's personal appearance, what was there in his manner of work to explain all he got through? His biographer gives as the following explanation :- "To a natmally good eapacity, he united the greatest degree of persererance. This enabled him to sumount various obstacles, that in the course of his practice niturally occurred. The want of a good memory olliged him to 
be methodical; and, ly great, and it maty les saill, a tmoly smprising regulatity, he so economised his tine, als to he rapalble of engiging

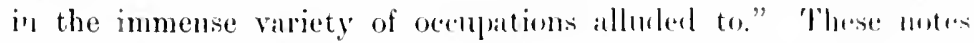
(1) help his defective memory are elsewhere referred to it amounting to no less than 40,000 . When casting aromul for the other canses of his great snceesi nne sees that lettsom munt

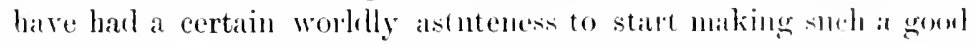
income so early and to eontinne at it for so long. A hint als to his shrewdness is conveged in the approbiatinn with which lo inotes Samuel Fothergill's advice: "Pleatse thy master, anm] ahove all please thy mistress." Lettsom, althongh a keen and independent observer, a ready writer and a frepuenter of on Medical society, never made any striking contribution to medical science. He had no great hospital ilpointment; he barl no pmpils to spread his fame; and he had no position at the Conrt or in the College of Physicians to give him prestige. His snccess in practice must have been due to his own personality, his sincerity, his great industry, and his direct influence npon his pattients. It is almudantly evirlent from his letters, that he enjored not only the exereise of his art, but the opportunity it gave his hroal humanity, to he a real comforter and friend to his patients. In onr he writes: "This I know, that I never lost a patient in a family that I diel not acunire the whole family ly it," for "I think a humane physician, who evinces by his conduct a tender interest in the recovery of his patient, never loses reputation by an event which no human means coull prevent; on the contrary, often times nearer attachments are acquired." He evidently had the happy knack of getting on easy terms with his patients; he had Miralueatu's "rlon terrible de la familiarité," for he writes, "I wonll rather be familiarly happy than acquire distant veneration" (Letter 9, March 13th, 1783). Being a Quaker, he har no crest or coat-of-alms: but the motto on his bookplate is Dum Spiras Spes. 


\section{LatTSOM'Y Chamanter.}

lt was possibly his equable temperament, and his placidity in the presence of disaster, which led to the well-known lampoon:

"When any sick to me apply,

I physicks, blects, \& sweats 'em;

If after that they choose to die,

What's that to me,

\section{LETT:OM."*}

'This lampoon was evidently wirlely known. A reference to it is enshrinerl in the 'Ingoldshy Legends,' in the poem, "The Wedding l)ay":

"It length, after no little climour" and din,

The toul air let wit and the fresh air let in,

They drag one and all

Up into the hall,

Where a medical Quiker, the wreat Dr. Lettsom,

Who's one of the party, 'hleeds, physicks, and sweats 'en.'."

* Amongst of leer rersions of thin aft-quoted surse are the following :-

"When patienul-come to I

1 physick-, bleeds, \& swats 'num;

Then-if the chume 10 die,

What's that tor I-l lets 'em.

and

(I. LetTSON).

"When ans patients call in haste, I phrsieks, bleeds, and - waits 'em,

If after that they choose to dic, Well. then, I lets 'em.

anil

"If in folk applies to I,

I blisters, bleeds, \& sweats 'em;

If after that they please to clir, Well, then, I lets 'em.

:1111

“. I, John Let.tsom,

Blisters, bleeds, \& sweats em;

If after that they plase to die,

I, John, lets 'em.

and

"Sou say I'm dead, I sil! you lie,

I pliysicks, bleeds, \& sweats' em ;

If after this my patients die.

Why, verily-J. Lets 'em.

He eridently believed in bleeding, for we read that in 1795, from exeessive exertion in his profession, he was attaeked with fever, for which he was under the necessity of losing 110 ounces of llood. 
His pliability maty have led to his being carricatured in the "Westminster Vagazine' of September', 1782, mmler the title of "Dr. Wriggle or the art of rising in physic." He philosophically refers to this as "Very complimentary ; for whit is greater honour, when an enemy professedly attempts to injure yom, that yon have so lived, as to leave him ineapable of saying a bad thing of you?" (letter 3, Octoher 16th, 1782). Through his long correspondence there is no hint that he was ever angry with or retaliated on his enemies. On the contrary, by calm reasoning and the soft answer that turneth away wrath, he generally canried conviction and won over his aulversary, ats is shown by his controversies with the Critieal and the Monthly Reviews. Yet Lettson's early rise and long career, as the leading physician in London, must have excited the envy of his less prosperous, though possibly better endowed, contemporaries, and his success in practice must have stirred the jealousy and malevolence of his colleagues of the baser sort. Yet the fact that, without these endowments, he moved freely in professional eircles, an intimate friend of leaders of thought at home and abroad, taking a prominent part in the scientific life and social progress of his country, is good evidence of his own sturdy independence and well-justified self-regard; while his acceptation by the profession, and the absence of jealousy and cabals against him, show that he was a good real more than a merely "fashionable physician," and that the superior persons in our ranks-probably as common in the 18 th as in the 20 th century - recognised his worth, or miserably failed to thwart his eareer. This is the more remarkable when we remember that he lived in a generation when bitter controversies, violent quarrels, seurrilons lampoons, abusive language, and passionate insults were as common in the calm of scientific circles as in the public life of the day.

Lettsom did not seek to escape enmity by fearing to speak out, or by refraining from earrying any project through to a successful end. Yet many of his projects met with violent opposition, abuse, and ridicule, and in his loyalty to them and to his friends he must often have risked damaging his professional career. As a fervent disciple of his friend Edward Jenner he warmly espoused the cause of Vaccination at a time when it was still abused and opposed, with the result that, "in Germany, vaccination had nearly extinguished the small-pox," and "was more general in every part of Europe than in England." (Fig. 8.) Jemner writes to Lettsom : "I 
have considerer London as the centre of opposition to the Vaccine practice" (Letter 135, November 23rd, 1811). Evidently this British discovery of medicine, in the 1 sth century, met with the same reception in its native land as did Lister's in surgery, in the 19th century. His support of the Humane Society, his enthusiasm for the improvement of prisons, his divagations into the work of the Philosophical Society, certainly show no self-seeking, did not improve his professional status, encountered strong opposition, and required much courage. His crusade for the Mangel Wurzel, as is seen in Boswell's rerses, only exposed him to ridicule. He dicl not flineh at opposing fashion, or fear to show that he had a frugal mind, when he animadverted upon the practice of wearing the hair powdered, as umnecessarily consuming a vast quantity of flour. He undertook the ungrateful task of exposing quackery. In reference to his attaek on the urine-quacks-mentioned in Shakespeare* and still flourishing in the 18 th century-Dr. A. Fothergill writes to him :- "Your successful eflorts entitle you to the warmest thanks of the public in general, and to the united acknowledgement of the faculty in particular. For you alone undertook the Herculean task, when you ought to have had the joint assistance of the College and every individual in the facnlty, in hunting down this many-hearled hydra" (Letter 228, October 27th, 1779). Courage could never have failed him, and it must be due to his suariter in modo that he was able to do so much and yet preserve his position and his friends. An instance of this courage in private life is shown by the charming, delicate, and feeling letter he wrote to his friend Boswell, deploring that "in scenes of pleasure which I have cordially enjoyed .... I have observed, not merely a too frequent use of the glass, but that mixture of liquors which, as a professional mau, I can add, tends to injure the best human fal,rick" (Letter 219, Jume 18th, 1791). This effort "to chasten and to moderate the fascinating influence of social pleasme" required courage as well as tact, and was done in such an evidently sincere and friendly way that we are glad to see that Boswell in his reply wrote: "I am not cheerful at present; the visible wearing away of Sir Joshua Reynolds depresses me much; and, besides, I have not been so attentive as I should be to your most friendly recommendations as to regimen. spero meliora" (Letter 220 , January 27 th, 1792).

* See Annual Oration on "Shakespeare and Medicine," 'Trans. Med. Soc.,' rol. $\operatorname{xxxix}, 1916$, p. 279. 


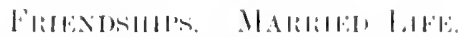

bettsom apparenty had the gift of friendship and the gentle ant of not making enemies. He was on gond terms with ali and smontry

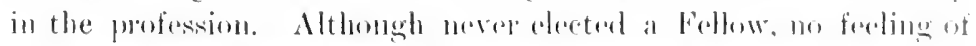

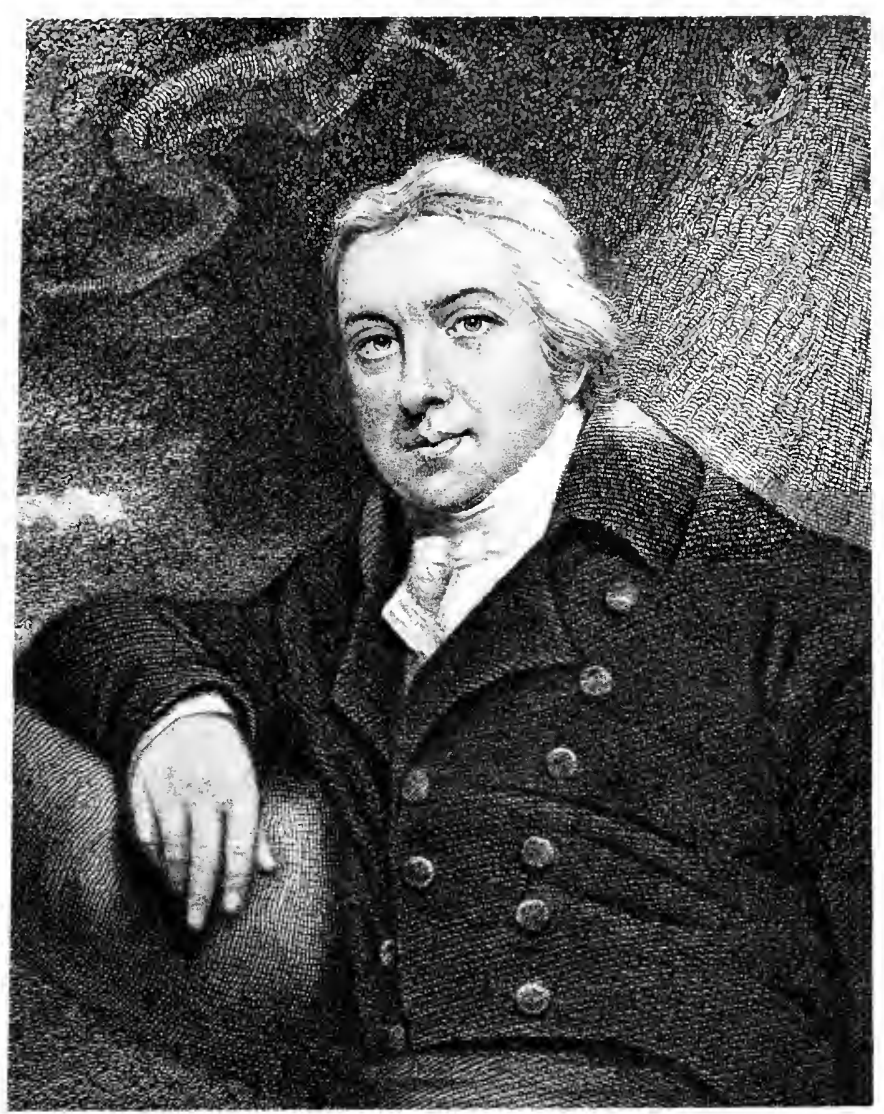

Fig, 4.-- Eulwarl Jemner, Fellow of the Medical Society of Lomilon. (See lage 23. ) (From an englaving hy F. S. Soriven, after I. R. Smitlı).

resentment at having been passed over prevented him from attending the Royal College of Physicians on October 1sth, 181:;, to hear the Oration by Dr. Williams of Oxford, and dine with the Fellows. The dimner was doubtless in the afternonn-probably 
abont three o'clock-for he records that he presider the same evening at the Medical Society.

Another of his friendly and sociable meetings with his colleagnes shows how cordial were his relations with many of them, and also indicates that already, in 1813, Harley street had commencerl to be a resort of medical men. Thus, under the rlate of December 3rd, 1813, he writes in his Diary: "Dinerl with Dr. Latham, Harley Street, with Drs. Maton, Robertr, and Young-Surgeons Sir Everard Horne, Sir William Blizzard, and Mr. Clive, constituting a very interesting and agrecable party." On November 20th, 1813, he dined with Mr. Pettigrew in .Bolt Colt and "passed a pleasant meeting till very late." He was then nearly seventy years of age, but it is evident that he was full of the joie de vire, ready to please and be pleased, and he seldom refers to a social gathering without commending the "pleasing conviviality" which markerl it.

Had Lettsom been as chaste as ice and pure as snow, we know he conld not have escaped calumny. It is the more remarkable that his biographer only finds it necessary to defend his memory from two suggestions. One was because, "by those who were ignorant of his true character, he had been accused of a licentions attachment to the fair sex." This slander is treated as an idle story based on an exaggeration of his enthusiastic attachment to womanhood. He loved the company and conversation of enlightened women, and this "may account for an unguardedness of behaviour which subjected him to severe censure-he was imprudent, but certainly not vicions." In his sixty-eighth year Lettsom frankly writes that in the society of young women, "in whom the sympathies and tender passions are most predominant, I have always found $m y$ mind humanized and improved, for virtue, innocence, beanty, and feminine chaste manners cannot but prove impressive, and produce a feeling of gratification, that is more than human."* $\mathrm{He}$ evidently lived on good terms with his wife, possibly all the more faithfully, as they did not see too much of one another! While he was plunged in his work in London, and living in Sambrook Conrt, she appears to have passed much of her time at Grove Hill, where "he generally dined on Sundays, and occasionally slept there." This will explain a reference to his wife in one of his letters: "I love her after 14 years' yoking better than in the honeymoon, and, wert thon yoked likewise, I could add

* 'Diary' of Jamuary 2nd, 1813. 
something, perhaps new, upon the economy of love. Half the mhappy comples I have seen have been among dimdlets, who have always been abont their wife's apron-strings-not considering that 'the sweetest honey is loathsome, in its own delicionsness . . . I find that those short intervals of my wife's company attords a higher realism of her society, and makes a volatile Creole, in his nature and essence changeable, more fixed to an object where familiatity hats not cloyed, and sentinent has not hecome insipid" (Letter 11, April 19th, 1783).

'The only other charge against Lettsom's ehanacter to which his biographer thinks it necessary to reply is that of vanity, and to this he answers: "It is admitted. Where is the individual that could withstand all temptation to vanity, and if he found himself every lay, both in public and in private, the theme of an unamimous applause and approbation. There is little or no harm in a morlest indulgence of the miversal passion, so long as a conscionsness of the rectitule of our motives and the uprightness of our conduct preaches self-reproach."

\section{L.eTTSOM'S VITALITY.}

Lettsom's vitality must have been enormons. His diary seldom refers to any bodily weakness; he may be "very much harassed by charitable applications," or "considerably tired by late hours," but we may judge that his ailments were not serious, as he thinks it worth making the pathetic note, "Had my last tooth drawn to-day by Mr. Heath." This was on December 29 th, 1813, in his 69 th year. Two days later (New Year's Eve) he writes, "At this period, with gratitude to the author of all good, that my state of health is apparently as good as at any period and my professional engagements have exceeded those of the two preceding years. . . " Although as early as his 39th year be talks of "the buffetings of his slender" habit and weak constitution," yet in his 66 th year he yrites, "I am as alert as in the days of my youth" (Letter 30, May 15th, 1810). Still he is sufficiently anxious at times about his health to write "I fancy immediately upon illness that I am going to the Majority; but," he at once adds, "feeling some little comfort in having done something in the world, which persuades me that I shall meet my predecessors with pleasure, I soon sleep my distempers off." He must have been a sound sleeper, for, as I have already narrated, he 
often did not have 20 minutes' leisure in a week; he passerl 19 years in London without a single holiday; and from the age of 23 he was "in perpetual exertion" in his profession. As an illustration of his vigour in advanced life, his popularity, his zeal in office, and his wide general interests, I would refer to his association with the Philosophical Society of London. He was admitted a Member on Iarch 10th, 1812 (he was then 68 years of age), and at unce took such an active interest in it that in October of the same rear he was unanimously chosen President. Although such a bust man he punctually and constantly attended the weekly meetings, and we read that his conduct in the chair, his regulation of the discussion, his useful practical hints, his support of the "juvenile eftort" and his "mild conciliatory mamers" gave the highest satisfaction. Next year he delivered the Ammual Oration and four Lectures on the following subjects: 1. On the Natural History and Medical Qualities of Tea; 2. On the Injurious Effects of Hard Drinking; 3. On the Natural History and Medical Qualities of Coffee; 4. On the Substances which have been used to describe Events and convey Ideas, from the earliest date to the Invention of Paper. In lolt he gave two lectures on Mind in Travelling and on the Evolution and Improvement of the Mental and Corporal Powers, and, in 1815, the year of his death, he gave two on the Philosophy of Youthfiul Sports.

\section{DEATH oF LETTSOM.}

To such a temperament as Lettsom's death came as he would have wished it-swiftly and mercifully. On October 2.2nci, 1815Waterloo year-he assisted at a post-mortem examination, remaining for two hours in a cold room. Next day he felt chilly and unwell, lut this did not prevent him from writing a long letter to his friend Dr. Dixon, of Whitehaven, in which he discussed a variety of matters and, amongst others, the fact that he was preparing for' the press a new edition of his 'Naturalist's Companion.' He added, "I am serenty years of age, and I wish it may be in the lispensation of the Author of all good to lengthen me out another rear to effect some literary objects before I emigrate red sedes" whereas unde negat redire quemquam." (Letter 12\&, October ․:3rd, 1815.) His wish was not to be granted. On the 25th he wrote a note saying he had had a rigor followed by a drearlful night, 
but that he was up and intent on seeing a few patients. He arlderl, "for the last 27 years 1 have not ben comfined by illuess." Two days later he was urgerl to see Dr. Babington, hut answered "that he shonld be better in a few days, and that hr wished for. III one to attend him." llis clauntless spirit, in spite of the entreaties of his friends, took him ont to see a poor patient in Whitecross Street, hut on his return he had to be lifted from his earriage, and that rening took to his berl. Even here, and in spite of exernciating pain which prevented him from turning without assistance, he was eager to get reports on his patients, and to make arraugements to be present at the approaching Anniversary of the Philosophical Society, which he was anxious to attencl, provided he was only able to sit up, and even if he hat to forego the duty of speaking at it. On the following day, October 30th, he ippeared improver-possibly in consequence of the mmsual though short rest after 27 years at full speed--but, next day, great debility came on, and he died on Wednesday, November 1st, 1815, between 3 and 4 o'clock in the morning, ten rlays after performing the post mortem, and five lays after he had been ont to risit his last patient. He was in his 71 st year. He had warmed both hands against the fire of life, and, when it sank, we can see that he was ready to depart. 


\section{JOHN COAKLEY LETISOM.}

M.1). Leyden, June 29th, 1769.

Fellow of the Royal Society, 1773.

Licentiate of the Royal College of Physicians, London, June 25th, 1770.

Member of the Royal College of Physicians, London.

Fellow of the Society of Antiquaries, $17 \% 0$.

Fellow of the Royal College of Pbysicians of Edinburgh, 1768.

L.L.D. Cambridge (Mass., U.S.A.).

Physirian Extraordioary to the City of London Lying-in Irospital and to the General IIospital, Aldersgate Street.

\section{Official Honour.}

1786. Hon. Member of the Colchester Medical Societr.

1788. Hon. Member of the Royal Medical Society of Edinburgh.

1789. Hon. Member of the Agricultural Soeiety of Amsterdam.

1789. Hon. Member of the Bath Agricultural Society.

1790. Hember of the Academy of Arts and Sciences, Montpellier.

1790. Hon. Member of the Medical Society, Moutpeilier.

1791. Hon. Member of the Royal Physical society, Edinburgh.

1791. Fellow of the Royal College of Physicians, Edinburgh.

1791. Corresponding Member of the Medical Society of Bristol.

1792. Corresponding Member of the Royal Academy of Seiences, Montpellier.

1793. Honorary Member of the Philosophical Society of Neweastle.

1796. Hon. Member of the Medical Society of Aberdeen.

1813. Hon. Member of the Horticultural Societs of Edinburgh.

Fellow of the Limuan boejety.

$$
\text { Honours from timesice. }
$$

1788. Fellow of the Mmerican Academy of $A$ rts and scicnees.

1789. Fellow of the Medieal Societies of New York and Newharen.

1790. Member of the University of Cambridge, Massiclusetts.

L.L.D. Unirersity of Cambridge, Mass.

1791. Hon. Member of the Massachusetts Hunane Society.

1792. Hon. Member of the Medieal Society, Massachusetts.

179:. Member of the Pennsylvanian Society for Pronoting the Abolition of slavery.

1792. Member of the Massichusetts Historicinl Soriety.

1793. Hon. Member of the Massachusetts Agricultural Society.

1795. Corresponding Member of the Historical Society at Boston.

1798. Hon. Member and one of the Conservators of the Hospital of New Fork.

1801. Hon. Member of the Iumane Society of Mhiladelphis.

1802. Associate of the College of Physicians of Philadelphia.

1803. Hon. Member of the Medical Society of Philadelphia

1808. Corresponding Member of the Medical Lyceum of Philadelplia.

1813. Hon. Member of the New York Historieal Society. 


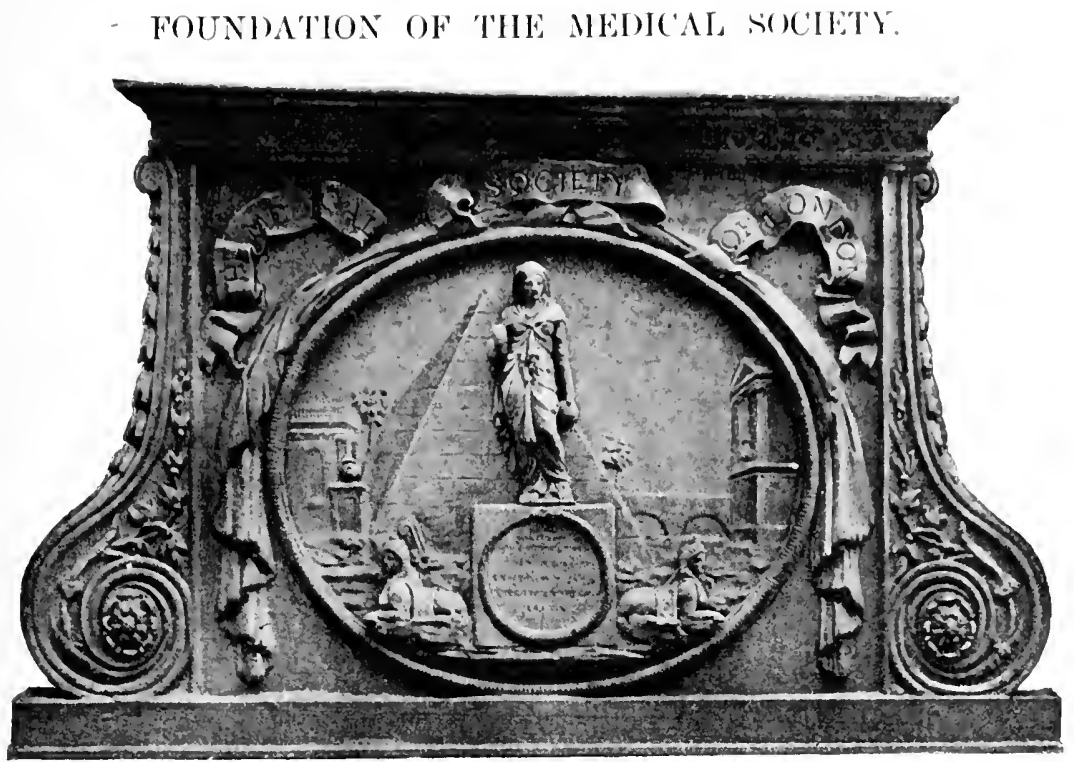

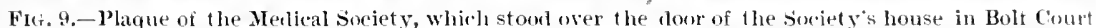
for 12s years (compare Fig. 11), and is now aflixed over the nantelpiese in ilie fresent home of the society." (see lave 45.)

I have completed this sketch of our Founder's life lefore descrilying when and how our Medical Society came into existence, and here I can be brief, as the subject has been well dealt with by Mr. George Bethell in his "Account of the Library of the Medical society of London," printed in vol. xxxvii of our. 'Transactions,' 1914.

Lettsom's multifarious writings were frequently issued in the form of short pamphlets to which he gave the title of 'Hints.' On June 23rd, 1773, he issued a pamphlet entitled 'Hints on the Establishment of a Medical Society of London.' The vigour with which he followed up design by action is shown by the fact that the Society was inangurated that same year, and the completeness with which he planned his scheme is demonstrated by observing that the "statutes" he drew up in 24 pages are in such order and detail that there will be found but trifling points of difference when we compare them with our present Rules of 145 years later. After an introduction in which he says 
that focieties "excite a generous ardour in liberal minds and raise even envy itself into useful emulation" and that "the principal part of our knowledge must be ever deriverl from comparing our observations with those of others," he points out the advantages of discussion, the usefulness of homorary rewarels, and the virtue of a Medical Library. At first the society was limited to 30 physicians, 30 surgeons, and 30 apothecaries, with a certain number of Honorary and Corresponding Nembers ("Nemoirs of the Medical Society of Iondon,' Tol. I, 1787). We still follow Lettsom's original design in meeting on a Monday, in on Annual Subscription being one guinea, in our methor of ballot, the mumber of ont Officers, in the very order of our business, in our two General Meetings annually, in our Annual Oration, and in numerous other details of the Society's regular existence. Naturally, having: leceived the ristinction of following the illustrious Lettsom in this honourable Chair, I turned with particular interest to inform unself of his directions to the Presidents of all time. I note that the President "shall regulate all debates, and prevent any from heing prosecuted upon trivial subjects," "state and put all questions, according to the intention of the movers"; "summon all extraorrlinary meetings of the Society, and enforce the execution of their statutes"; "shall have a second vote when the suftirages are equal," and that "all Members shall pary implicit obedience to the President, in the execution of his oftice." I do not know whether the formal phraseology of our method of initiating a new Fellow was existent before Lettsom's time, but we strictly follow his direction that "the President shall take him by the hand, saying. "In the name and by the anthority of the Medical society of London, I admit you a Fellow thereof." The only one of Lettsom's statutes which we appear to have quite neglected is No. 4, Chapter IV, where it is enacted that "the Presirlent, whilst in the Chair, shall be covered, except when addressing himself to the whole society,"-as he is shown in Fig. 16, p. 54. These 'Hints' as to our foundation are so complete in every detail that they contain one illustration showing our first medal (Fig. 10, p. 43), mother of a silhonette engraving of John Fothergill. M.D., to whose memory the Medal is dedicater, and a drawing of the scrpent of Esculipius coiled round an altar.

But not only ricl Lettsom draw up this remarkably complete hesign of a society, and promptly carry it into execution, but he 
supplemented it ly a liberal gift of several hmolvent volumes amol valuable manuseripts.

'The early meetings of the society were held in lattsom's homes
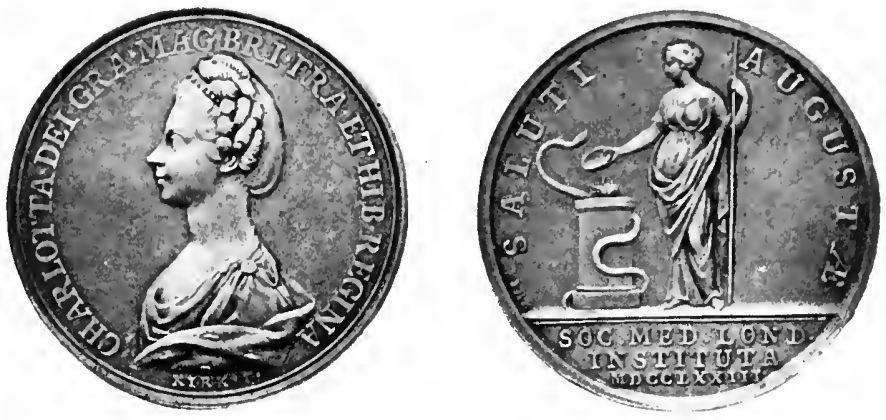

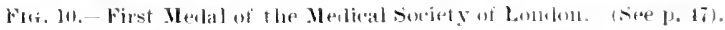

in Sambrook Court, Basinghall street, and its first home was in Crane Court, Fleet Street. Here the Medical Society remained intil 1788, when Lettsom presented it with the freehold of a house in Bolt Court, Fleet Street, where it was established until 1850 (Fig. 11). It is lare for benefactors to make such handsome gifts lnring their lifetime; the house in Bolt Court was ralined at $£ 2,500$. The shifting of the centre of medieal life more westwarl led to our then taking a house in George Street. Hanover Square, and we were finally established in our present house in Chandos street in 1871.

\section{Medely's Picture.}

The fine picture in this room shows a group of the Foumder's of the Society, the central figure being Lettsom standing up in the act of presenting the deeds of our Bolt Comrt house to the Presilent (Fig. 16). This oil-painting by Samuel Medley is a valued possession of our Society. Medley, it seems, had been under some obligation to the President, Dr. Sims, and in return for the services rendered to him, painted a portrait of his friend (Fig. 15, p. 50). This was so good a likeness that Sims engaged the artist to paint a meeting of the Society. Medley was the better able to execute this as he was the associate and intimate companion of Lettsom, Sims Babington, Blair, Hooper and Jenner. The painting contains .2 life-like portraits of our Founders, most of them being the 


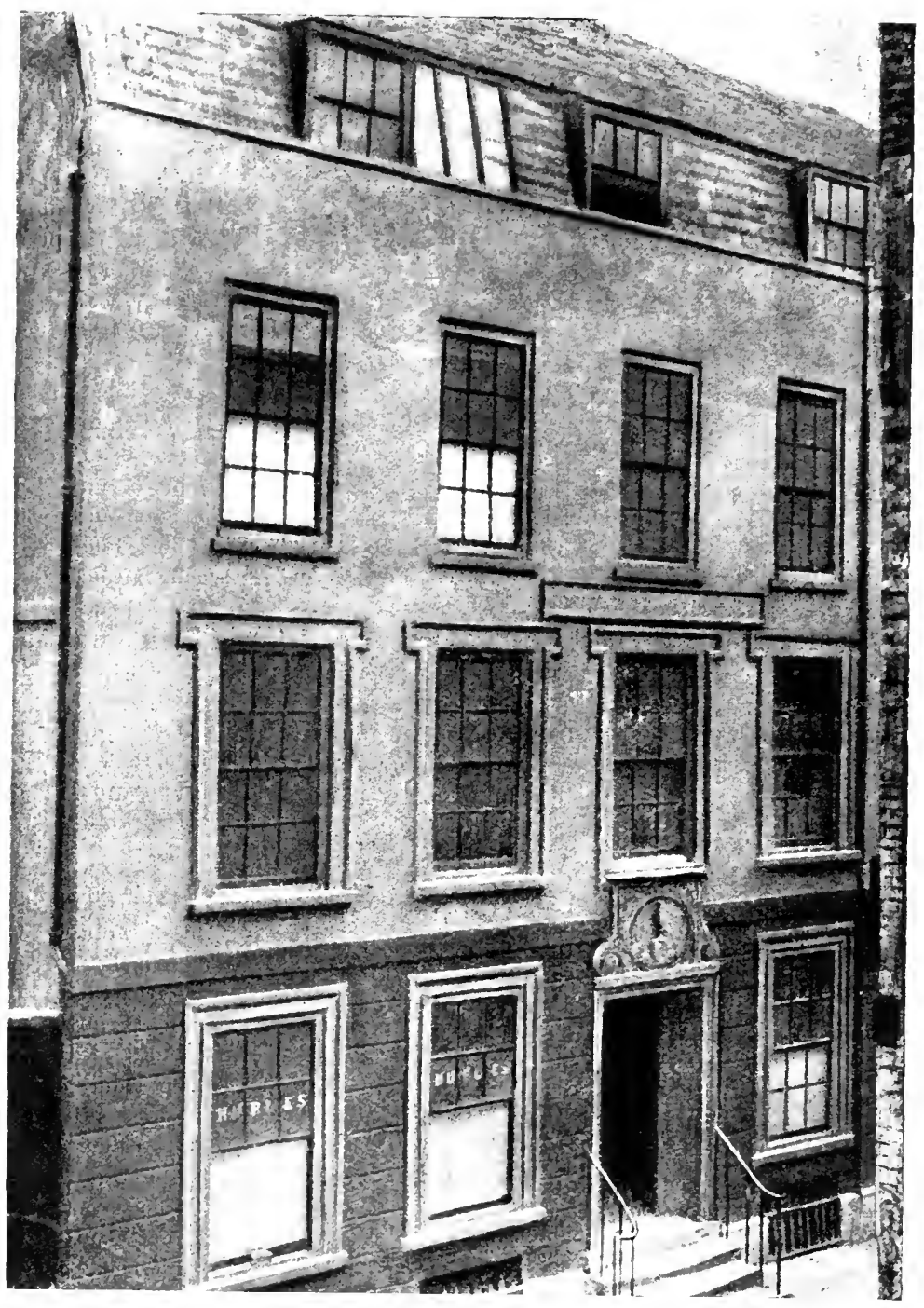

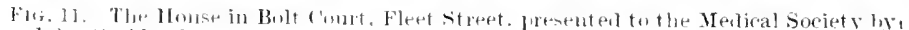

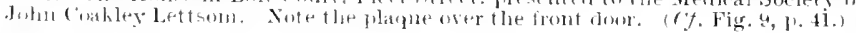

learling medical men of the perind. It is doultitul if there exists amother merlical picture containing so many actnal portraits of well-known individuals. Elward Jemner is represented standing 
close to the left shoulder of the Presilent. It will be moticer that his figure is smaller than the other's, and somewhat out of ferrspective. This is becanse . Temer was not one of the original Fommlers, and did not appear in the picture as ariginally painted. His portrait, in consideration of his celebrity, was painted in later. This pictme was engraved by Nathaniel Branwhite in 1801, and copies of this are still in existence, with Jenner's fignre albsent. It will be noticed that the President is seater, and, following Lettsom's 'Hints,' he remains covered and is wearing his cocked hat.

\section{The Sochety's P'Lanete.}

We all know the tablet which stands above the mantelpiece in our Library (Fig. 9). It is a bas-relief, beantifully modelled in a clay, on which is stamped "Coade's Lithodipyra," and the date 1787. Inside a carved wooden horder is the title "The Nedical Society of London"; beneath this is a draped oval, on which an allegorical group is modelled in relief. In the distance, and forming the background, appears the Great Pyramid of Egypt, skirted by palms. In front of this, and in the centre, the principal figure is that of the goddess, the Isis of Sais, on a pedestal. Thjs goddess is supposed to have been the discoverer of medicine and of the value of drugs. Amongst other functions she presided at hirths and rocked the cradle of the Nile. In brief, she was Nature. In her left hand she holds a globe and in the right some ears of corn. Crouched on each side of this is a sphinx, emblematic of mystery. A bridge over a river, a temple, a broken column, and an urn on an altar are also represented. On the front of the pedestal is a coiled serpent, representing eternity, and within the circle is the following inscription :-

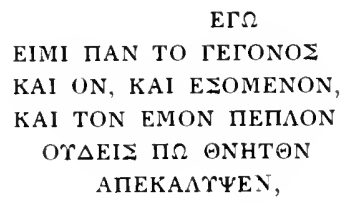

signifying "I am what ever is, or has been, and will be; and no mortal has hitherto drawn aside the veil."

This identical plaque is the one Lettsom ereeted over the doorway 
of our Society's House in Bolt Court in 1788 (Fig. 11), and there it stoot the wind and the rain until our Comueil remover it last year to its present site in the next room.**

Lettsom must have been much impressed with this emblematic gromp and with the inscription, for he had an exactly similar tablet erected over the front façade of his house at Camberwell, as we know by a reference to p. 38 of the Rer. Thomas Maurice's descriptive poem "Grove Hill." He also introducerl a large and particularly good ilhstration of it on the title page of his "Life of Fothergill.' In this latter print the figure of the goddess has both arms intact." +

The house in bolt Cout remained in our possession until the year 1916, when it was disposed of.

\section{'The P'resident's Badrit.}

The President's Badge dates from the year 1901, when it was presented to the Society by Sir William Henry Allchin, M.D. during his Presitency (Fig. 12). It is taken from the obverse of

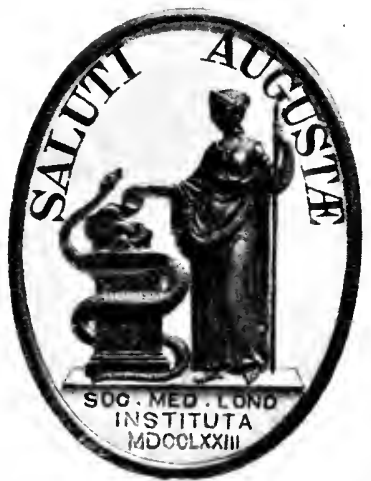

Fur, 12.-Badge worn by the President of the Merlical soriel y.

the medal illustrated in Lettsom's 'Hints for' the Establishment of a Medical Society in London,' written in 1773, and published at 1. 257 of Vol. ii of his collected 'Hints' (sce Fig. 10, p. 4:3). In an

* See 'Tians. Med. Sue. London,' vol. xl, 1917, p. xlriii.

+ 'Vemoir's of John Fothergill, M.D., ly John Coakley Lett-mu. 4tlı ed. Londun: Printerl hy C'. Dills, 1786 . 
ovil is the figure of Hygeia, with the mame and date of fommolation of the society below. Above is the motto "Siluti Augustir," signifying "For the welfare of London." The old lioman name of our city was Lundinim, lnt in the reign of Valentinimm the Elrler the ofticial name of London was ehauged to Angusta. This hitppened A.D. 36x, on the occasion of the trimmphant entry of General 'Theotosins, afterwards Emperor, into London (Sir Arthur Wans, 'Proc. Soc. Antiq.,' 1915, Vol. xxvii, p. 105).

lombini saluti is the form in which the inseription appeal's on the crest imprinted on the title page of our 'Transactions.."

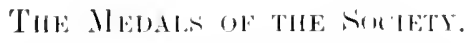

In Lettsom's 'Hints for the Lstahlishment of a Merlical society' in London.' written in 1773 , there is a plate illustrating the two sides of a medal, with the title "I'rize Merlal of the Medical Society of London." 'This doubtless was the first design of the Fothergillian Golul Medal, rahed ten guineas. But, in 178t, it was decider that this medal should bear the head of Dr. John Fothergill on one side, and, on the reverse, a rivic wreath; hence we may look on the merlal illustrated in Lettsom's Hints rather as a foundation, or commemorition, medal. It is curions that the Society has never possessed a copy of this merlal until the present session, when, through the interest of my friend, Dr. Raymond Crawfurd, one was discovered, wrongly catalogned, amidst a job lot of medals at one of the Red Cross sales at Christie's anction rooms. The Registrar, Mr. Bethell, not only hat the good fortune to secure the medal, but also the generosity to present it as a gift to the Society. It is engraved by John Kirk.

The obverse of the medal, as already described, is almost identical with the President's Barlge. We have not been able to diseover why the bust of Queen Caroline should appear on the reverse.

The Fothergillian Medal, " in gold of ten guineas valne," was fornded by Lettsom in a letter addressed to the Fellows of the Society on May 25th, 1784 . This medal was afterwards permanently endowed ly Dr. Anthony Fothergill, who left $£ 500$ to the society for that purpose. This Dr. Fothergill was not related to 
his nilmesake, Lettsom's friend and protector, on the anniversary of whose birthday (March 8th, 1712), the medal is adjurlicated.*
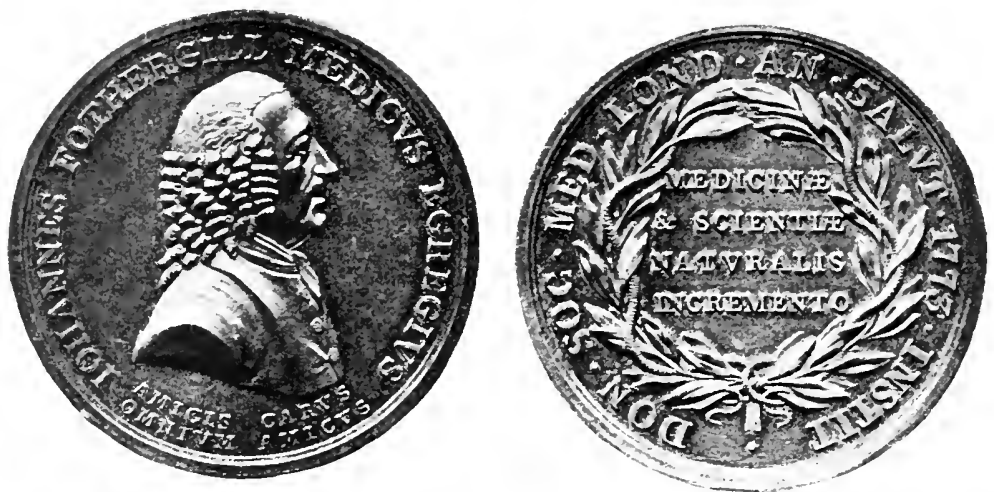

Furi. 12,-John Fothergill IIedal.

In 1791 lettsom himself won the prize essay for the Fothergillian Gold Medal with a thesis in reply to the question, "What are the Diseases more prevalent in great Towns? and what are the hes
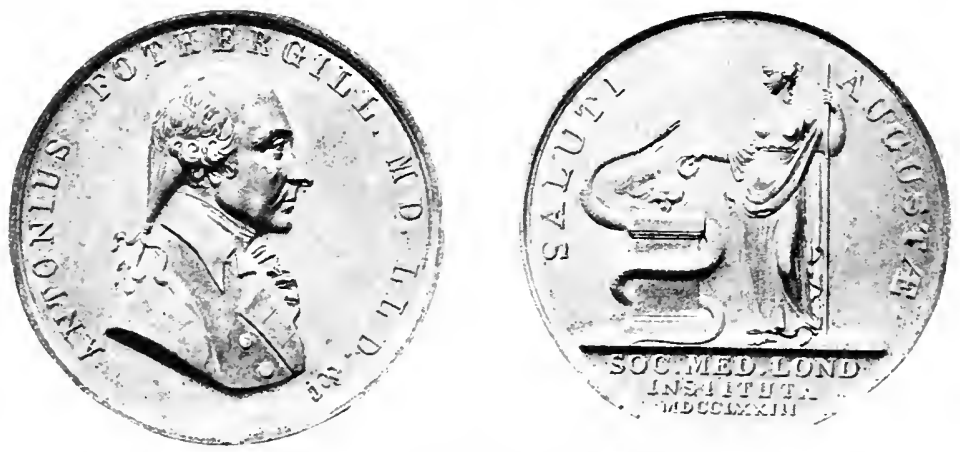

Fitr. 14.-Anthony Fothergill Merlal.

means of obriating them? and the history of Epidemics for at least one year?" He delivered the Annual Oration in 1778, choosing as a subject 'History of the Origin of Medicine.' This was reprinted at the request of the Society, and the quarto volume of 170 pages, which I here exhibit with illustrations, copious foot-notes from

* "A Note on the Fothergillian Medals of the Medical Society of Loudon," hr John Langton and George Bethell, 'Trans. Med. Soe. London,' rol. xxriii, 1915, p. 3336 . 
100 anthors, and an index, will demonstrate the reading and research he must have devoted to this rliflicult subject.* He said he har to deliver this Oration at short notice, hut was able to eflect it hy the facility with which he combl refer to his 10,000 notes: How dill he manage it in those days before card-filing systens were invented ! $\uparrow$ This llistory was so appreciated that it wats translated and published in French in 1787. On March sith, 180t, he again relivered the Inmual Oration, "On the Origin of Vaccine Inocula tion with a Bingraphical account of 19. . lemner," to whom the Fothergillian (iold Medal was then presented.

\section{EAliK DAYS OF THE ŚOCHET.}

So the Medical Society was fomoled, and I would refer those interested in its early years to consult the article by Mr. Bethell and the Oration on the subject of "The Old Founders and the New Honorary Fellows," delivered by Dr. E. Symes. Thompson on May lst, 188:. 1t would appear that these years were not free from anxieties, caused chicfly by petty jealousies leading to financial difficulties. Thus, the first year's income was only $£ 73$ : it fell later to $\mathfrak{2 2}^{2}$; and in the year the Bolt Court premises were presenterl (178s) it reached $\mathfrak{E}+18$. Compare this with our income of E1,5Si 6. 1d. in 1915. In 1800 a number of books were bought flom the President, Dr. James Sims, for the large sum of $\mathfrak{E} 500$, the Society also engaying to pay an annuity of $£ 30$ to Dr. Sims and his wife. This Dr. Sims was a native of County Down (Fig. 15). He probably had the political talent which Irishmen appear to develop when they leave the Emerald Isle, for he managed to be re-elected President for a period of 22 consecutive years, i.e. from 1786 to 1809 . Medley's painting shows him in the Presidential Chair, and the portrait of the good-humoured, pleasant

* Reviewing this Oration, the 'Monthly Cittalogne' for July, 1779, writes: "On Medical Historian las rendered his oration equally instructive and amusing, by numerous anecdotes and quotations, in the form of notes; and by a till more numerous hist of references, which evines an immense share of multifarions reading, well digested and applied."

† My friend, Mr. J. Y. W. MacAlister, the secretary of the Royal Society of Medicine, writes to me that card indexes were designed and used long before our American cousins bronght them to our notice. The original cards, in the handwriting of the French abbe who invented them, are still in use in the Bibliothèque Nationale in Paris (circa? 1740). 
ann sagacions face looking ont helow his corked hat agrees with what we know of his character. (Fig. 16, J.54.) Ilis constant reclection, inced, proved mufortunate for the societs, and led to the secession of a number of influential Fellows and the formation in

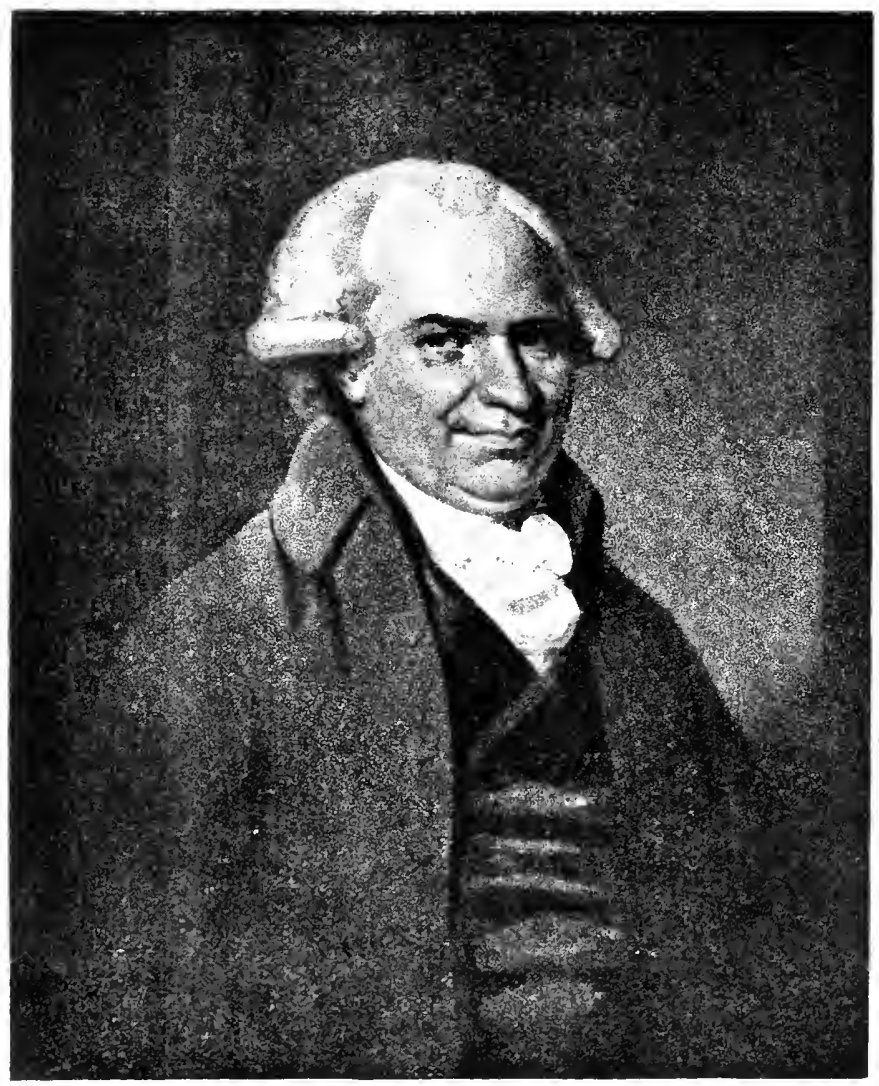

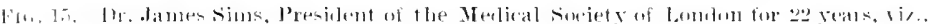

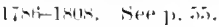

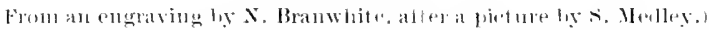

1:05 of the Royal Merlical and Chirurgical society, the prealecessor of the lingal Suciety of Medicine. However, 1)r. Lettimn-who hard alleady heen President in 1755 - bonke down I)r. Sims' retention of the Chair and was again l'resident luth in 1no9 and 1si: 
In 1850 the Society perpetmated the name of and Fomder by rstablishing the Lettsomian Lectures.

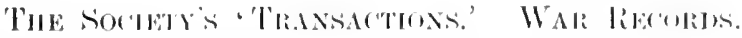

The published records of the Society's work appearenl nurler the title of ' Memoins ' or 'Iroceedings,' and, later on, muler the present me of 'Transactions.' We find they exist from 1787 to 1805 , and from 1810 to 1817 , lnt between these two periods then is a hiatus. sinlisequently there appeared only one volume in 1546 and another in 1861. 'The publication of the 'Tlansactions' was resumed in 1572, and they have appeared ammally ever since.

To the 'Memoin's' and 'Transactions' of our Soriety' lettson marle no less than 27 contributions ('Life,' vol. i, 1) 1:36).

As our 'Transactions' covered the period of the Penimsula and Waterloo campaigns, I looked through them to see in what way they reflected the military medicine and surgery of the period. I confess to considerable surprise in not finding a single communication referring to the wars in which our country was then engagerl. This is striking when we remember that, in the Session of 1915-16, every single communication made to the society was on a war subject, with the one exception of the Anmual Oration by myself on "Shakespeare and Medicine." But it is also noticuble that the Boer War is reflected in our "Transactions" hy one solitary communication on 'Typhoid Fever.' This shows that our previous wars have been of the nation's life a thing apart--the present worlll war embraces our whole existence.

\section{Records of the I)EATHs of SHakesteare AN1) NElsox.}

1 had occasion last year in "Shakespeare and Nedicine," to point out that our Society possesses the only record of the nature of the deith of onr national poet. ${ }^{*}$ It is curious that we also possess : record of the death wound of our national hero, Nelson. The Minute Book of the Medical Society for December 23rd, 1815, contains the following,-_" A letter was read by Dr. Gillespie from the surgeon on board 'The Victory,' who dissected the wound of the late Admiral Nelson, deseribing the progress of the musket ball. It passed throngh the left shoulder, penetrating one lobe of the lung,

* "Shakespeare and Medicine," by Nir StClair 'Thom-on, 'Trans. Med. Sor., wol. xxxix, p. 258 (1916). 
and, after perforating the vertebrat, was lodged in the surrounding muscles."

Surgeon WT. Beatty (afterwards sir William Beatty) was the surgeon on board H.M.S. "Victory" and snbsequently in 1807 he published a book with the title "Authentic Narrative of the Death of Lord Nelson, with the Cireumstances Preceding, Attending and Subseynent to that Event. The Professional Report of his Lorrlship's Mound. and Several Interesting Anecdotes.'

\section{The Iatin Fory of Nomixition.}

In wur early days, Latin was the official language of the society. $\mathrm{II}^{+} \mathrm{e}$ are fortmate in possessing a copy of the form of nomination in nse at the end of the 18th century. It is dated 1789, and is arldresserl to Mr. William Vyse, Surgeon, at spalding in Lincolnshire, and has been presented to us by that gentleman's greatgrandson, Dr. Christopher Vise, of Tunbridge Wells, now serving with the Army. He represents the sixth generation of medical nen in one family, is one of our Fellows, and is present here this evening. The Latin form is printed, and the translation accompanying it is in the handwriting of Willan Chamberlain, the celelmated obstetrician whose name is well known in comnection with the invention of midwifery forceps.*

*

"Viro Celeberrimo Guielmu, Vyate, C'hirurgo P'ruen

"et Societas Medica Londinensis, s. P.I).

"Nominis Tui fama, tot ac tanta, quie in Arte nostra illustrduda, promo. renda, amplificanda edidisti specimina, nos impulerunt, ut in socionm exterorum, quos Correspondentes rocant, numermm Te al-criberemus; id y god die Lunee, tertio Augusti, 17s9, factum esse pritsente-te-tantur littere. Cuire henigno accipe animo hoc amicitiæ et reverentix nostra erga Te testimonimm at fue pro benerolentia Tua, ea, quæ ad artis incrementum aliquid conferunt, nobisem communica. Tale ae nobis fave

Lomelini,

$$
\begin{aligned}
& \text { "Guliedues Chamberlatie, } \\
& \text { "ad epistolis ad exterm. }
\end{aligned}
$$

- Ex redibus Societatis,

"Bolt Court, Fleet Street.

"Die Martis, tto Augusti, 1789."

Translation.

"The President and Members of the Medieal society in London wish nuch health to the most renound Willium l'ise, surgeon.

"The greatness of your reputation, in so many and great instances, which you have giren in illustrating, promoting and enlarging our art, hare induct 


\section{Ciñugron.}

The rest of the chronicles of the Medical Soriety, and all that it hat done, are they not written in the himblsme wohumes of the 'Transations'. - al storehouse of interest and instraction to all our members? In this sketch of our Fonnder I hope I have succeederl in strengthening the loyilty of all Feliows to the oldest Medical Sinciety in London, and in conveying to your minds the attractive pincure of the chanacter of our Founder which I have receiverl from at periasal of his life and letter's. It is well summanisert by his biographer, who descriles Dr. John Coakley Lettsom as "good, humane, benevolent. Thongh himself not leamer in the highest anceptation of the term he was the friend and the patron of learming." "I have lost in him the sensible, firm and upright friend, the able, honest and experienced physician, and the pleasing, instructive companion of a social hour." Onr society need rek for no hetter exemplar.

\section{Biblogikaphy Consulted.}

Thuman James Pettigrew, Memoirs of the Life and Writings of the late John Cuakley Lettson, with a Felection from his curespondence.' In 2 vols. Lopdon, 1817.

Tuhn Coakley Lettrom, 'Memuins of John Fothergill, M.D.' Funrth Edition. London, printed hy (: Dilly, 1786.

Thrmas Joseph Pettigrew, 'Selections from the Medical Papers and Correspondence of the late John Coakley Lettrom, M.I): London. Longman, Hurst, Rees, Orme, and Brown, 1817.

Jolm Coakley Lettson, "Hints designed to promote Beneficence, 'Temperance, and Medical Science.' 3 vols. London, J. Mamman, 1801.

Philip Mainwaring Johnston, 'Transacs. London am Micldlesex Archroogical Society' September 20 th, 1913.

ur. to armit you into the number of our absent Members, whom we catl Correspondents; which this present Letter testifys was done on Mordar, the $3 d$ of Augnst, 1789. Wherefore receive kindly this testimony of our friendship and regard for rou, and ont of your good will communicate to us any oceurrences that conduce to the improrement of the Art. Farewell and think well of $n$.

'Lumion,

"Gulielates Cinamberiaive.

- Bolt Conrt, Fleet street,

"Tuesday, th of turg. 17s9." 


\section{APPENDIX.}

\section{THE FOENIERS OF THE MEDICAL SOCIETY OF LONDON, 1773 .}

(From the painting by himuel Nedley.)*

For many of the biographical notes of the 22 medical worthies whose portraits appear in this valuable picture, I am indel,ted to the Anmual Oration delivered lefore the Society by Dr. E. Symes Thompson on May 1st, 1882. (See Fig. 16.)

1. Dr. John Cunker Letwon is seen standing to address the Fellows. He may be in the act of presenting the lease of his honse in Bolt Conrt to the Society (Fig. 11, p. 4t), or he maly be giving the recorrl of the life of Dl: John Fothergill, to whom he was so much attached, or he might be delivering the Oration, which he did both in 1778 and again in 1804 . If it represents him in the first year of the Soeiety's existence, he would then be 29 years of age. It will be noticed that he wears a bob-wig, unpowdered, that his clothes are of solver cut, and his stockings of plain style and material.

2 . The handsome figure seated on Lettsom's left hand is that of Sir JoHn HaYes (1750-1809), whose white silk stockings form so prominent a feature in the forefront of the picture. He was a person whom Nedley, the artist, userl to speak of as "the most tinished contier of lis acrulaintance." Born at Limerick, he graduated at Rheims. Then he distinguished himself as an arny surgeon, and hecame Physician to the Forces and L.R.C.P. in

* The artint, samuel Medler, was born in 1769 and died in 1857. He was the son of the celebrated Baptist minister, immuel Medley, and beeame a painter of religions and historical subjects. Snbsequently he took up prortraiture, in whilh depurtment of his art he obtained considerable reputation. His health suffered from his sedentary work and he therefore gare up art, in 1805, and took to the Stork Exchange. At the latter oeeupation he was sucessful and made a lirre fortune, Medley was an autive man outside his professional oceupations, and he is known as one of the Founders of Unirersity College, London. His eldest danghter married Heury Thompson and beeame the mother of the late Sir Henry Thompson, F.R.C.S., well known as an artist and exhibitor at the Royal Academy, in addition to being Surgeon to University College Hospital. He resided the latter part of his life at Chatham and died there. 


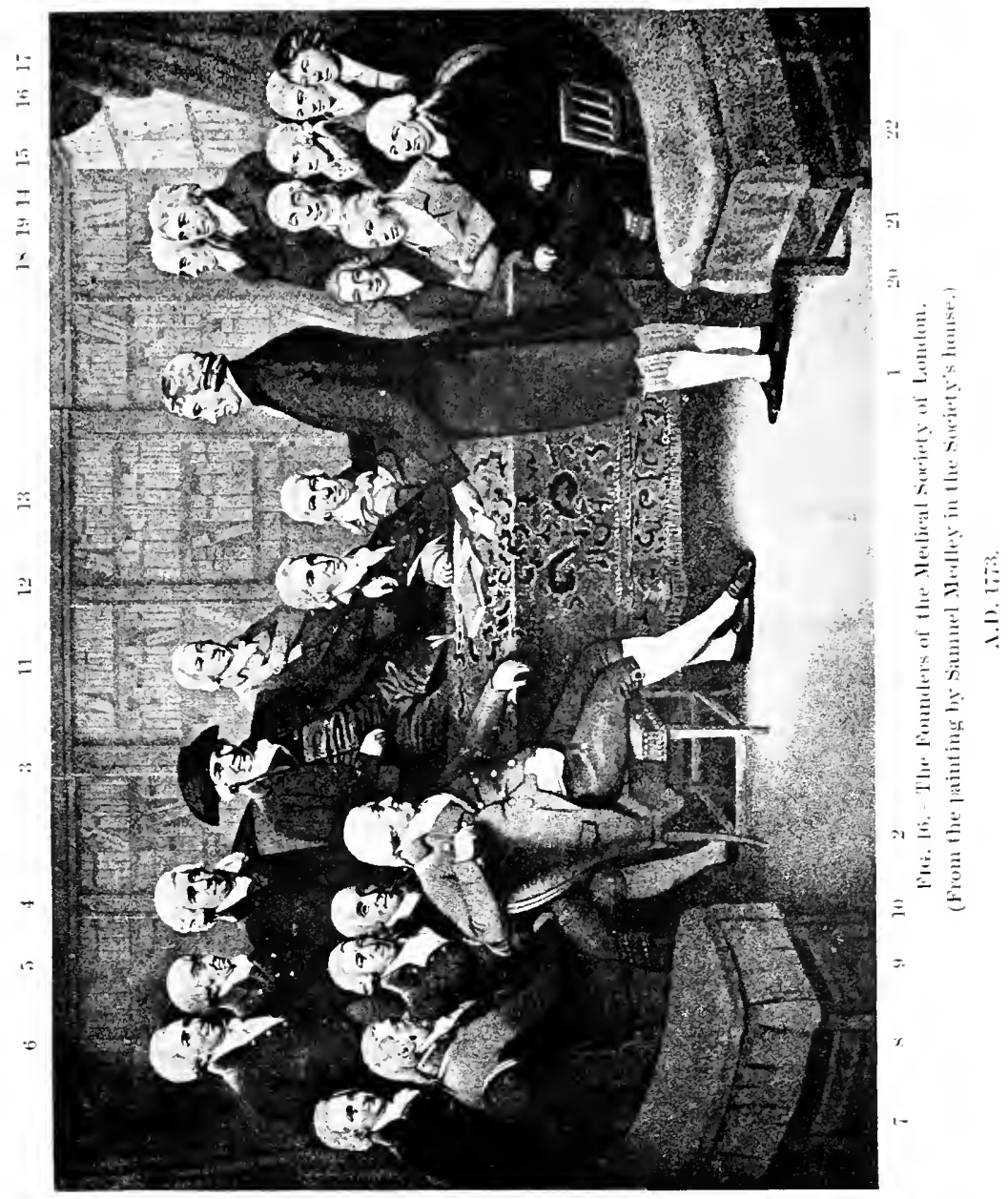





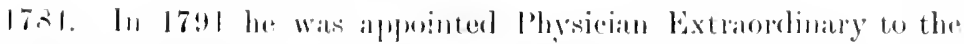
lrime of Willes, and in the following rear Hhysian to the

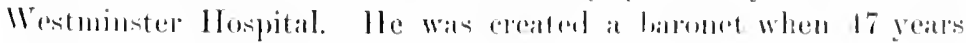

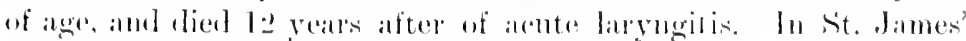
Choreh, l'iecarlilly, moles the morth gallery, there is a small mural thlet to his menomy. letrols and despatches from Sijr latph Mereromby, Loml Moira, loml Somthanptom. Mr. Huskisson, and] others, now in the possession of the family. show how much the: snecess of the Ilavamah campalign was doe to the muting devotion, skill, and energy of Sir. John (then I)r.) IIayes.

3. Dr. JAMks Sus $(1741-1520)$ is jighty representer in the l'residential Chair, for he possessed to an extraordinary degree the power of ruling the elections of the society, and manager to lue re-elected President during a perjod of 2.2 years (Fig. 15, 1. 50). His constant re-clection, inleed, proved unfortmate for the Society, and led to the secession of a 11 mbler of influential Fellows, and the formation in 1805 of the lioyal Medical ame Chimrgical Society, which, in 1907, hecame merged in the Royal socjety of Merlicine. 1). Nims was born in Comty lown in $17+1$, attended the metropolitan hospitals, and studied at Elinburgh, but, like many of his con temporarjes, took his degree at Leyclen. His suceess in practice ats an acconchem was greatly due to the recommendations of Lettson, with whom he establisher the lioval Humane Society. He was Physieian to the Aldersgate and Surrey Dispensaries, and wrote much, as our 'Transactions' testify. For instance, one day he recolded a rale case of absess above the clavicle, communicating with the lung, so as to blow ont a emalle. His chief writings are 'Observations on Epidemic Disorders, with liemarks on Nervon. and Malignant Fevers,' a 'Discourse on the Best Method of Prosecuting Medical Inquiries,' and 'The Principles and Praetice of Milwifery.' He drew attention to the value of nitrate of silver in epilepsy ancl chorea, giving it in doses of gl. !, but stated that he had heard of a physician in town who gave it to the extent of 18 grains a day. In 1795 he spoke of the value of arsenic in intermittent fever, and of elaterimm in llopsy. He was a goodhumoured, pleasant man, as his sagacions face would suggest, full of anectote, an ample reservoir of good things, and for figmes anc faets a perfect chronicle of other times. He had a most retentive memory, but, when that failed, he referred to a compendium of knowledge in the shape of a pocket-book, from which he quoter 
with oracular anthority. In the first year of the century our Society purchased from Dr. Sims a large number of books for the sum of $£ 500$, and engaged to pay an atnnuity of $£ 30$ to Ir. Sims. and afterwards to his willow, should he pre-deceatse her. Probably no medical society ever expended so large a sum at one time in the purchase of books from a private library.

4. Dr. 'Thomas Bradefey (1751-1813), being deaf, placed himself as near to the President as possible, and is shown standing on his right in his accustomed attitude, with a hand behind the ear so as to concentrate the sonnd. He was born in Worcestershire, and there for years conducted a school where mathematics-in which he was proficient -were specially tanght. Retiring from scholastic life he took his degree at Edinluurgh, settled in Londion, and hecame l'hysician to the Westminster Hospital. He was for years the editor of the 'Medical and Phrsical Jomrnal.' His deafness, his retiring habits and scholarly life. unfitterl him for metropolitan practice, to which be proved mequal rather from diffidence than from lack of professional knowledge. He alwars hesitated in drawing conchusions from uncertain premises, and appeared to little advantage in the sick room.

5. Immediately behind Dr. Thomats Bradley stands. Tanes Ware, F.R.S. (1756-1815). We are reminded of his interest in ophthalmic surgery by his gold-rimmed spectacles. He was celebrated for extracting cataract with a success that, it is said, had rarely been equalled. He wrote several works on ophthalmology, and founderl the sichool for the Indigent Blind.

(i. Edward Nathaxied Baxchoft, M.I), F.R.s. (17-2-1842), is at the extreme left in the picture of the three figures standing on the Presilient's right hand. Born in London in 17 72 , he graduated Bachelor of Medicine, Cambridge, in 1794 . In the following year he was appointed I'hysician to the Army and, in this capacity, served in the Windward. Islands, in Portugal, the Mediterranean, and Egypt. Returning to London in 180t, he qualified as Doctor of Medicine, and was elected F.R.C.P. Lond. in 1806. He was censur in 1 $1 \times 06$. He was elected Physiciun to St. George's Hospital in $1 \mathrm{~s} 0 \mathrm{~s}$, but retired, owing to ill-health, in $1 \times 11$, and proceeded to . Tamaica as Physician to the Forces. Dr. Baneroft tierl there in 1842. He was the anthor of a number of works on Yellow Ferer. the 'Philosophy of Permanent C'olours.' and was an authority on lotany and natural history. He wrote ipon the subject of the 
'Medical thepartment of the Army, complaining of the distinction

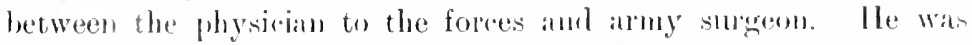
a stroms oppment of the theory of spontaneons gencration of diserises.

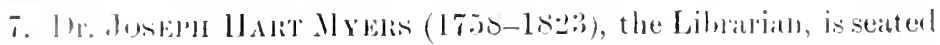
to the extreme left of the pieture. Born of Jewish parents in New lork, he was sent to London at an early age, and commencerl his merlianl studies hy attendance at the lectures of William IIunter. and 1)r. George Fordyce. From landon he went to Edinburgh, where he took his M.1). in 1779. Elected L.R.C.P. Loud. in 1787, he settled in Jomelon, and was appointed l'hysician to the l'ortuguese Hospital and the General Dispensary. He died . June lst. 1ヘ20.

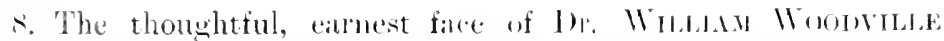
(1752-1805), whose peruke is well shown in the picture, ealls for a few worls. He is sented. with his legs erossed. on the left side of thr picture below 1). Myers, but nearer the spectator. Born at Cuckermonth in 175:. he took his M.I). degree in Edinburgh in 1755 , and first practised in his native county of Cumberland. He settled in London, 17-st. and was electerl Physician to the Smallpox and Inoenlation Huspitals. He was an acemplisherl hotanist, and in the gardens of the Smallpox Hospital near King's Cross, two acres in extent, he cultivatert his hobly, and worked up with artistic accuraty the illustration for his work on 'Medical Hotany,' published in four quartu volumes in 1790-94. He has left us valuable works ou smallpox. lut his great botanical work is still comsulted with profit and pleasure. William Woodville was secretary of the Medical socicty in 17st, when liettsom established the gold medal as a memorial of 1 r. Fothergill, to be given on his birthday (March 8th). His letter acknowlerlging the gift is printed at the end of Lettoom's life of Fothergill. At first Woodville was vigoronsly opposerl to hemer's great discovery of vaccination, but the opportunity aflorded by the Medical Society to bring then together was nsed by lemmer to argue and remonstrate with him. The discussion alpears to have been conducted with much heat, Both, however, were equally engaged in seeking after truth, and our society was the meeting ground which enabled Jenner to convert Woodville from a strong opponent to an active supporter. He raceinated multitudes of people, some thousands of whom be afterwards tested by variolous inoculation, and thus gave the 
public a confidence in viccination which conk not otherwise have heen attained. Dr. Woorlville cultivated the society of his professional friends, by whom he was much esteemed. He rlier of dropsy in March, 180.5, and, being a Quaker, was buried in the same Friends' lurial ground as our founder Lettsom. .John Bunyan and other nonconformists are buried near by, at Bumbill Fields.

9. Dr. Nathanier. Hulane (1732-1807), who sits next Dr. Woorville, was a vigorons Yorkshireman, who took the M.I). Edinburgh in 1765 , at the age of 33 , and was appointed Physician to the Charterhouse and 1.R.C.P. in 177t. He was aloo an F.R.S. He died at the age of 75 from a fall from the top of his staircase to the hasement. He wrote works on the prevention of scurvy, recommending lime-juice, a remedy which, he stated, har been known since the sixteenth century. He also wrote on puerperal ferer, on gout and stone. The epitiph in Charterhouse Church states that "he practised medieine during a long course of years with advantage to his patients and honour to himself."

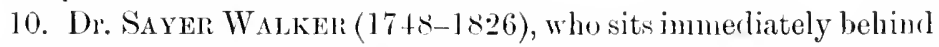
the white-stockinged figure of Sir Tohn Hayes, was a colleague of Dr. Hulme, at the Lomdon lying-in Hospital. He was at first a Presbyterian Minister at Enfield, then, when it years of age, took the Aberdeen M.J). amd, after 20 years of olsstetric practice, retired to Clapton and clied in 18.8. He wrote treatises on "Nerrous I) iseases' and on the 'I)iseases of Women.' He was the first to give turpentine in Trenia, and stated at a meeting of this Soeicty that it bat proved snceessful in his hands in 90 cases.

11. EDWARD JeNNER $(17+9-1823)$ stands immediately on the President's left (compare Fig. 8, p. 35). It is interesting to notice that this portrait was absent from the original picture when first engraverl. After Jemner's grand discoveries (in 1796) had received the acknowledgement of the Society, and he had been elected to the Fellowship, it was thought right to add the portrait of one so distinguisherl to the existing picture. This was accordingly done, but copies of the engraving by Branwhite are still in existence, in which Jemner's figure is absent. It will be noticed that he is put in the backgroumd, and that his figure is on a somewhat smaller scale than the others. From the very first year of our Society's existence, when Dr. Lettsom read a paper on "Inoculation," that sul,ject held a prominent place. In 1801, Dr. Jemer was himself present on several successive evenings, when cow-pox ocenpied the attention of the Fellows. 
Jenner hat been a Corresponting Fellow for l. years, when in 1802 he was elected an orlinaly fellow; and in the following yan the value of his discovery to the world was exprestenl in al highly appreciative menorial drawn up by the Society.

It wonld be of interest, while speaking of Jemner, th give an accout of vaccination, and the important function onr sreiety fulfille! in atlording an opportunity for full and frequent disenssion in every stage of the controversy ; lut this has been done with great eare and completeness hy 1). Cholmeley. The reprotel of having undervalued, or having heen slow to appreciate the value of Jenner's work, cannot be passed upon our Fommlers ; although the tardy recognition of it hy the Houses of Parliament, who voted him only $£ 10,000$, and years after $£ 20,000$ more, mily, hy the light of subsequent events, deserve that reproach.

12. Dr. Robert Hoopsis (1773-1835), as recretary, sits at the President's left hand. He wits M.D. of St. Andrews, and practised in Savile Row. From time to time he brought many interesting cases before the Society. He mentioned that of a man who harl a pitchfork driven into his head for 4 inches and speedily got well; and of another person who quickly recovered after having nearly half his cranium taken off in the riots of 1780 . He wrote on Intestinal Worms, and edited a medical directory.

13. Mr. Edward Forin (1746-1809) who sits next lut one to the President's left hand, read a paper in November, 1779, on "Loss of Voice Cured by Electricity." This method of treatment was taken up by Dr. Hooper, who, in 1783, and again in 1787 , reported cases of periodic headache cured ly electricity, with partieulars of animal magnetism. He wrote a valuable work on diseases of the hip-joint.

14. Of the four who sit in the back row, to the right of the picture, the one nearest to Lettsom is Dr. JoIn Haighton (175j-182:3). He was an accomplished anitomist, physiologist, physician, and accoucheur. His knowledge of the physiology and cliseases of the uterus was so superior that he gave this part of Mr. Cline's anatomical lectures by the latter's particular desire. He was one of those praetitioners who were proseeuted by the Royal College of Physicians for exercising his art without a licence. Dr. Haighton's defence was that he would willingly submit to the strictest examination and pay the fees, but that he refused to withdraw from practice, reside for two years at a university, and attend lectures delivered by men much his inferior in every department of 
merdicine. He began life as a surgeon in the Guards, then became Demonstrator of Anatomy in the Borongh School of Medicine and lecturer on Physiology, and for many years he was regarded as the al,lest teacher of midwifery in Europe. He was physician to the Eastern Dispensary for some years, until obliged to relinquish it on acconnt of the extent of his practice. His manners were ahrupt. anit his temper petulant, and to this his friends attributed the fact that he never entered the state of matrimony. He suffered from chronic laryngitis, and publisherl a series of experiments on the laryngeal and recurrent branches of the eighth pair of nerves; also experimental inquiries on the reproduction of nerves and on animal impregnation. His papers in the early volumes of the "Transactions " of our Society, viz., three on "The Canses of Vomiting," are full of original icleas, and the freshness and rivacity of their arrangement is quite what might he expected from a man having the alert-not to say "wide-awake"-look which the artist Medley has so skilfully rendered in the picture.

15. Dr. R. I. Thoritus (1768-1837) sits second in the back row to the right, resting his chin on bis hand. He took an active part in promoting Jemner's views. He wrote 'A Vindication of Small-pox,' and a work in five volumes on 'The Philusophy of Medicine.' His best known works are his 'Practical Botany' and 'British Flora.' His face is one of remarkable intelligence. In October, 1806, he related before the Society a case in which he showed much vigour and fertility. He was called to a man who had humg himself with a silk pocket-handkerchief. The doctor applied a common bellows to une nostril, thus filling his lungs with air. Then he applied boiling water to the stomach, which immediately produced a convulsive groan and gisp. Nustard was then applied to the nostrils and it cataplasm to the feet, then a blister to the thorax, and after that leeches. The patient recovered and had suffered no pain!

16. Next to him is seated Mr. Johr Shadweld.

17. Dr. John Aikex (1747-1822) sits on the extreme right of the picture. His face is certainly a remarkable one. His wig, it will be noticed, is imnocent of powder. He was little fitted by temper or haljit for the fatigne and struggle necessary for success in town and he willingly and wisely followed the bent of his disposition, and devoted himself to literary pursuits. He settled at first at Chester, next at Warrington, and afterwards at Yarmouth, but. while there, being an ardent Dissenter (son of a Dissenting 
Minister), he tomk an active part in the political agitation (on nected with the l'peal of the 'T'est $\lambda$ ct, and was so npused hy the elergy, with whom he had previousty been populan, that he fomm is wise to move to London. His medieal works were mot so large or mmmerous ats his general ones, e.\%., 'Eranings at Ilome,' the -General Bibliographical Dictionary, 'Monthly Magazine, 'The Amunal liegister,' etc. He was the biographer of Howall, the philanthropist, and saw much of him at Warrington. Dr. Aiken, as well as Lettsom, acted in concert with Howarl in aneliorating the condition of prisons.

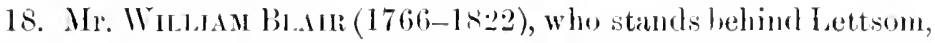
to the right of the picture, with the celebrated 1)r. Babington at his side, has a classical profile aml a look of alertuesis befitting so distingnished an operator. He was Surgeon to the Lock Hospital as well as to the Finshury and Bloomsbury Inspensaries. He lnought a case before the Society in which, a piece of meat having stuck in a person's throat, he used probangs without effect; but, by injecting tobacco into the bowel, he indueed vomiting and thus removed the obstacle. In amother case he performed resophagotomy with sucess. In 180; he gave letails of a rare case of hernia in which ascitic fluid escaped through a puncture in the tunica vaginalis. He edited with others a 'System of Surgery', and also edited the 'London Medieal Review and Magazine.'

19. Dr. Wifldam Babington (1756-1833) stands hehin! Lettsom, the nearest figure to the top right hand corner of the pictnre. $\mathrm{He}$ was born and educated in. Irekund, but completed his professional rourse at Guy's, and was early appointed on the statf of the Harlar Hospital. Being called upon to attend the prisoner's of war at Winchester he canght jail fever, and narrowly escaped with his life. After five year's of military work he became Apothecary to Guy's and Lecturer on Chemistry, and under the advice of Dr. Saunder's (who sits in the arm-chair nearer the spectator) he took the Edimburgh M.1). (legree, and in the same year was elected Physician to Guy's. His progress as a physician was rapid, and he very soon had an extensive city practice, so much so that in 1811 he was compelled to resign his hospital appointments. For many years Dr. Babington was the acknowledged head of the profession in the city. He was universally beloved and respeeted. Dr. Gooch wrote of him as a "man who, to the cultivation of modern sciences, adds the simplicity of ancient manners; whose eminent reputation and rare 
benevolence of heart have long shed a graceful lustre over the mrofession which looks up to him with a mingled feeling of respect, confidence and regard." He died in Devonshire Street in 1833, aged 77, of influenza. His statue was ereeted in St. Paul's Cathedral by public subscription. The inseription on this monument is by the pen of Dr. Paris, the President of the Royal College of Physicians. 1)r. Babington was a Fellow of the Royal Society, and one of the foruders of the Geological and Hunterian Societies, and was one of the best mineralogists of his time.

The name of Babington is of particular interest to myself, in common with all who practise laryngology, for his son came near to inventing the laryugoscope. In the year 1829 Dr. Benjamin Guy Bilhington showed his "glottiscope" to the Hunterian Society of London.* This consisted of a laryngeal mirror, very similar to those used at the present day. on which he concentrated the smin's rays by means of a common hanl looking-glass. There are no cases resorled in which Babington's glottiscope was employed, although he used it on many patients, and a method which depended on so mncertain a luminary as the sum-at least, in this climate-conld not be expected to secure any general arloption. Another objection was that it demanded the use of the operator's two hands, the right one holding the lary'ngeal mirror, while the left manipulated the handglatss. Still, in realising that the one mirror would suffice for reflecting light downwards into the larynx, and also for receiving the image of the parts thus illuminater, Baljington made a great advance on all previous efforts in this direction, and thus, by 26 year', he anticipated Gareia's invention of the laryngoscope in $1855 . \dagger$

20. Cluse behind Lettsom, seated in the lower row, we see R. Chaldin Combe (17+3-1817), who was erlncated at Harrow, and seemed the friendship of 1)r. William Hunter. He practised as an olsstetric physician, being elected to the British Lying-in Hospital in 1789. His attaimments as a scholar and antiquary, and his taste in numismatics, were generally known and appreciated. He was elected a Fellow of the Royal Socicty in 1776, and, amongst other

* "The Use of the Larmgoseope,' hy Morell Mackenzie, M.D. 3rd Edition, 1871. London: Longmans, Green and Co., p. 12.

+ StClair Thumsm, "The' History of the Laryngos"npe," "The Laryngoscope,' xง, March, 1905, p. 17t: Wilks and Bettau!, 'Ilistory of Guy's Hospital,' London, 1892, p. 235. 
Works, he homght out, comjointly with Mls. Homer, Fellow of

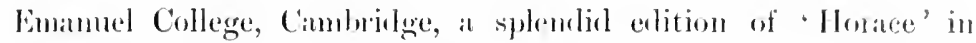
two volnmes, and said to antain the best inlex to the works of Honace whinh hats erer appeared. He died at his homse in Vermon Place, and was hmied in Blonmsbury (emetery, Bmonsick sifurare.

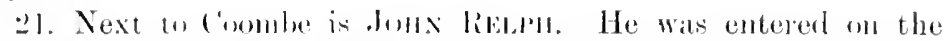
phisir line at leyden, in Mareh, 175s, and gramated M.I). there in the sime year. He hecame I.R.C.P. in 17.t, and l'hysician to Giny's, 1789. He wrote a work on "Pernvian Bark," and died in Mark lano in 1804.

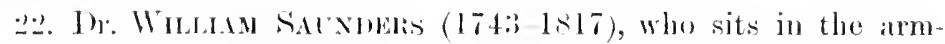
chair near the right-ham comer of the picture, the last of thr 22 Fommlers, was physician to the Middlesex and afterwards to st. Thomas's Hospital. like Relph, who was from Cumberland, Samblers was a north comotruman. He servel his apprenticeship at Penrith, and was then a pupil at St. Thomas's. He became an amy surgeon, and, when peace was estahlished, he settled at Penrith and took the M.I). of Aherdeen. He went again with the regiment to Minorea, and, while quartered in Edinlmrgh, attended medieal lectures there. He then went to America and was promoted to the rank of physician to the army, which he served with great credit to bimself and benefit to the troops. After the successful expedition against Havmmath he returned home with broken health. He, however, regained strength during a tour in France and Italy. Dr. William siunders hecame I.R.C.P. in 176.5 and settlert in pratice in London, and, in the following year, was appointed physician to the Mirtllesex and, in 1768, to St. Thomas's Hospital. When 5l years of age he marrier an heiress and gave up his hospital appointments to 1r. Reynolds, of Guildforr. Three years later his wife died, and his own health broke down, but he did not relinquish practice altogether. He was elected F.R.C.S. in 1784. He left two diughters. The elder became Viscomntess Melville and the younger Comntess of 11 estmoreland. 

